\title{
Impact of ultraviolet radiation on marine crustacean zooplankton and ichthyoplankton: a synthesis of results from the estuary and Gulf of St. Lawrence, Canada
}

\author{
Howard I. Browman ${ }^{1 *}$, Carolina Alonso Rodriguez ${ }^{1}$, France Béland ${ }^{1}$, \\ John J. Cullen ${ }^{3}$, Richard F. Davis ${ }^{3}$, Juliana H. M. Kouwenberg ${ }^{1, * *}$, Penelope S. Kuhn ${ }^{1, * * *}$, \\ Bruce McArthur ${ }^{4}$, Jeffrey A. Runge ${ }^{1}$, Jean-François St-Pierre ${ }^{1}$, Russell D. Vetter ${ }^{5}$
${ }^{1}$ Department of Fisheries and Oceans Canada, Maurice-Lamontagne Institute, Science Branch, Division of Ocean Sciences, Secondary Production and Recruitment Processes Section, 850 Route de la Mer, Mont-Joli, Québec G5H 3Z4, Canada ${ }^{2}$ Département d'Océanographie, Université du Québec à Rimouski, 300, allée des Ursulines, C.P. 3300, Rimouski, \\ Québec G5L 3A1, Canada
}

${ }^{3}$ Center for Environmental Observation Technology and Research, Department of Oceanography, Dalhousie University, Halifax, Nova Scotia B3H 3J1, Canada

${ }^{4}$ Environment Canada, Atmosphere Environment Service, Experimental Studies Division, 4905 Dufferin Street, Downsview, Ontario, M3H 5T4, Canada

${ }^{5}$ NOAA, Southwest Fisheries Science Center, 8604 La Jolla Shores Drive, La Jolla, California, USA 92038-92037

\begin{abstract}
The objectives of the research program reported upon here were (1) to measure ambient levels of UV radiation and determine which variables most strongly affected its attenuation in the waters of the estuary and Gulf of St. Lawrence, Canada; and (2) to investigate the potential direct impacts of UV radiation on species of crustacean zooplankton and fish whose early life stages are planktonic. In this geographic region, productivity-determining biophysical interactions occur in the upper 0 to $30 \mathrm{~m}$ of the water column. Measurements of the diffuse attenuation coefficients for ultraviolet-B radiation (UV-B, 280 to $320 \mathrm{~nm}$ ) at various locations in this region indicated maximum $10 \%$ depths (the depth to which $10 \%$ of the surface energy penetrates at a given wavelength) of 3 to $4 \mathrm{~m}$ at a wavelength of $310 \mathrm{~nm}$. Organisms residing in this layer-including the eggs and larvae of Calanus finmarchicus and Atlantic cod Gadus morhua-are exposed to biologically damaging levels of UV radiation. As a result of these physical and biological characteristics, this system offered a relevant opportunity to assess the impacts of UV on subarctic marine ecosystems. Eggs of $C$. finmarchicus were incubated under the sun, with and without the UV-B and/or UV-A ( 320 to $400 \mathrm{~nm}$ ) wavebands. UV-exposed eggs exhibited low percent hatching compared to those protected from UV: UV radiation had a strong negative impact on C. finmarchicus eggs. Further, percent hatching in UV-B-exposed eggs was not significantly lower than that in eggs exposed to UV-A only: under natural sunlight, UV-A radiation appeared to be more detrimental to C. finmarchicus embryos than was UV-B. In analogous experiments with Atlantic cod eggs, exposure to UV-B produced a significant negative effect. However, UV-A had no negative effect on cod eggs. Additional experiments using a solar simulator (SS) revealed high wavelength-dependent mortality in both $C$. finmarchicus and cod embryos exposed to UV. The strongest effects occurred under exposures to wavelengths below $312 \mathrm{~nm}$. At the shorter wavelengths (<305 nm) UV-B-induced mortality was strongly dose-dependent, but (for both C. finmarchicus and cod) not significantly influenced by dose-rate. Thus, at least within the limits of the exposures under which the biological weighting functions (BWFs) were generated, reciprocity held. The BWFs derived for UV-B-induced mortality in C. finmarchicus and cod eggs were similar in shape to the action spectrum for UV-B effects on naked DNA. Further, the wavelengthdependence of DNA damage was similar to that for the mortality effect. These observations suggest that UV-induced mortality in C. finmarchicus and cod eggs is a direct result of DNA damage. There was no evidence of a detrimental effect of UV-A radiation in these SS-derived results. A mathematical model that includes the BWFs, vertical mixing of eggs, meteorological and hydrographic conditions, and ozone depletion, indicates that UV-induced mortality in the C. finmarchicus egg population could be as high as $32.5 \%$, while the impact on the cod egg population was no more than $1.2 \%$. Variability in cloud cover, water transparency (and the variables that affect it), and vertical distribution and displacement of planktonic organisms within the mixed layer can all have a greater effect on the flux of UV-B radiation to which they are exposed than will ozone layer depletion at these latitudes. Our observations indicate that $C$. finmarchicus and cod eggs present in the first meter of the water column (likely only a small percentage of the total egg populations) are susceptible to UV radiation. However, although exposure to UV can negatively impact crustacean zooplankton and ichthyoplankton populations, these direct effects are likely minimal within the context of all the other environmental factors that produce the very high levels of mortality typically observed in their planktonic early life stages. The impact of indirect effects - which may well be of much greater import - has yet to be evaluated.
\end{abstract}

KEY WORDS: Atlantic cod · Gadus morhua $\cdot$ Calanus finmarchicus - UV-B - UV-A · Dissolved organic carbon · Underwater optics · Radiometry $\cdot$ Attenuation coefficients $\cdot$ Ozone depletion $\cdot$ Biological weighting functions $\cdot$ DNA damage $\cdot$ Cyclobutane pyrimidine dimers

Present addresses:

-Institute of Marine Research, Aquaculture Centre, Austevoll Aquaculture Research Station, 5392 Storebø, Norway.

E-mail: howard.browman@imr.no
"Columbia University, Biosphere 2 Center, 32540 South Biosphere Road, PO Box 689, Oracle, Arizona, 85623, USA

**"Department of Oceanography, Dalhousie University, Halifax, Nova Scotia B3H 3J1, Canada 


\section{INTRODUCTION}

\section{Stratospheric ozone and the impact of ultraviolet radiation}

Long-term data series on solar ultraviolet-B radiation (UV-B, 280 to $320 \mathrm{~nm}$ ) incident at the Earth's surface are rare. Nonetheless, those data available indicate that, over the past 10 to $15 \mathrm{yr}$, UV-B levels have increased significantly at mid-latitude areas of the Northern and Southern Hemispheres (Crutzen 1992, Kerr \& McElroy 1993, Madronich et al. 1995, Wardle et al. 1997). These increases in UV-B are linked to reductions of stratospheric ozone (Kerr \& McElroy 1993, Madronich 1994, Madronich et al. 1995). Severe seasonal reductions in ozone layer thickness are not restricted to the Antarctic: dramatic depletions have also been recorded over the Arctic (Fergusson \& Wardle 1998, Goutail et al. 1999). As a result of air mass mixing, deep ozone depletion at these high latitudes tends to draw ozone north and southward, resulting in ozone thinning at middle latitudes (Björn et al. 1998, Fergusson \& Wardle 1998, Goutail et al. 1999). Thus, ozone layer depletion, and concomitant increases in UV-B, are a world-wide phenomenon.

High spectral resolution measurements of UV-B are available for only a very small number of water columns (reviewed in Booth \& Morrow 1997, Franklin \& Forster 1997). However, it is clear that UV-B penetrates to greater depths than has previously been widely accepted (Booth \& Morrow 1997). Although the variables that affect UV-B attenuation are still under active investigation, particularly in marine environments (e.g. Kuhn et al. 1999), dissolved organic carbon (DOC) and chlorophyll a (chl a) appear to be important (Scully \& Lean 1994, Morris et al. 1995, Laurion et al. 1997).

A rapidly growing number of studies indicate that UV-B radiation, at current levels, is harmful to aquatic organisms and may reduce the productivity of marine ecosystems (e.g. Holm-Hansen et al, 1993, Siebeck et al. 1994, Häder et al. 1995). Such UV-B-induced reductions in productivity have been reported for phytoplankton, heterotrophs and zooplankton, the key intermediary levels of marine food chains (Damkaer 1982, Thomson 1986, Cullen \& Neale 1994, Chalker-Scott 1995, Smith \& Cullen 1995, Booth et al. 1997, Häder 1997). Analogous studies on planktonic fish eggs and larvae, although rare, indicate that exposure to levels of UV-B currently incident at the Earth's surface results in higher mortality that may lead to poorer recruitment to adult populations (Pommeranz 1974, Hunter et al. 1981, 1982, Williamson et al. 1997, Walters \& Ward 1998).

Within this general context, we undertook a research program to assess whether current levels and ozonedepletion-related increases in solar UV radiation have any direct effect on crustacean zooplankton and ichthyoplankton in the upper estuary and Gulf of St. Lawrence, Canada (Fig. 1A). As described in the following section, this system offers a relevant opportunity to assess the impacts of UV-B on subarctic marine ecosystems.

\section{Regional context: the Gulf of St. Lawrence, Canada}

Hydrographics. In some regions of the Gulf of St. Lawrence (Fig. 1A), the late spring and summer water column shows a pronounced thermocline between 10 and $30 \mathrm{~m}$ (Petrie et al. 1988, Koutitonsky \& Bugden 1991, Runge \& de Lafontaine 1996) (Fig. 1B). A cold intermediate layer ( $\mathrm{CIL},-1$ to $+1{ }^{\circ} \mathrm{C}$ ), situated at depths of 30 to $100 \mathrm{~m}$, separates the warm mixed layer near the surface (14 to $16^{\circ} \mathrm{C}$ in summer) from the waters at depth $\left(6^{\circ} \mathrm{C}\right)$ (Koutitonsky \& Bügden 1991, Runge \& de Lafontaine 1996, Gilbert \& Pettigrew 1997) (Fig. 1B). As a result of the spring-through-fall presence of this intermediate cold layer, the most important productivity-determining biophysical interactions occur in the upper 0 to $30 \mathrm{~m}$ of the water column (Therriault 1991, Ohman \& Runge 1994, Runge \& de Lafontaine 1996). During summer, the mixed layer in these waters is typically 10 to $15 \mathrm{~m}$ deep. The eggs and larvae of several commercially important marine invertebrates and fishes are found in this layer (Fortier et al. 1992, Runge \& de Lafontaine 1996) (Fig. 1C).

The research program. Following from the complete absence of information on levels of ultraviolet radiation (UV, 280 to $400 \mathrm{~nm}$ ) in the water columns of this region, and on the potential biological impacts of UV on the organisms present in the shallow mixed layer, the objectives of our research program were: (1) to measure ambient levels of UV radiation and determine which variables most strongly affected its attenuation; and (2) to investigate the potential impacts of UV radiation on species of crustacean zooplankton and fish whose early life stages are planktonic. A synthetic summary of these investigations is presented in the text that follows.

\section{UNDERWATER OPTICS}

Accurate measurement of spectral irradiance is fundamental to any study on the biological effects of UV radiation. High-resolution UV measurements are essential for the application of biological weighting functions (BWFs), especially for the shortest and most damaging wavelengths: 280 to $312 \mathrm{~nm}$ (Madronich 1993). Thus, in order to make an assessment of the biological impacts of UV radiation on crustacean zoo- 
Fig. 1. (A) Map of the estuary and Gulf of St. Lawrence, Canada, showing the location of stations at which high-resolution ultraviolet radiation ( 290 to $400 \mathrm{~nm}$ ) measurements were made in the surface waters of the region. Numbers in parentheses next to each station position are the $10 \%$ depth penetrations (the depth to which $10 \%$ of irradiance just below the surface penetrates) at a wavelength of $310 \mathrm{~nm}$. Water samples were obtained from these same stations and analyzed for chlorophyll $a$ and dissolved organic carbon content. (B) Vertical profiles for temperature and salinity-taken at Stn S27 on the map-illustrating the shallow spring-summer mixed layer. (C) Vertical distribution of Calanus finmarchicus eggs and nauplii, and gadid (including cod) eggs. The wavelength-specific $10 \%$ depth penetrations at Stn S27 (that with the clearest water) are superimposed over the egg vertical distributions in order to illustrate what percentage of the egg population is likely exposed to UV-B radiation

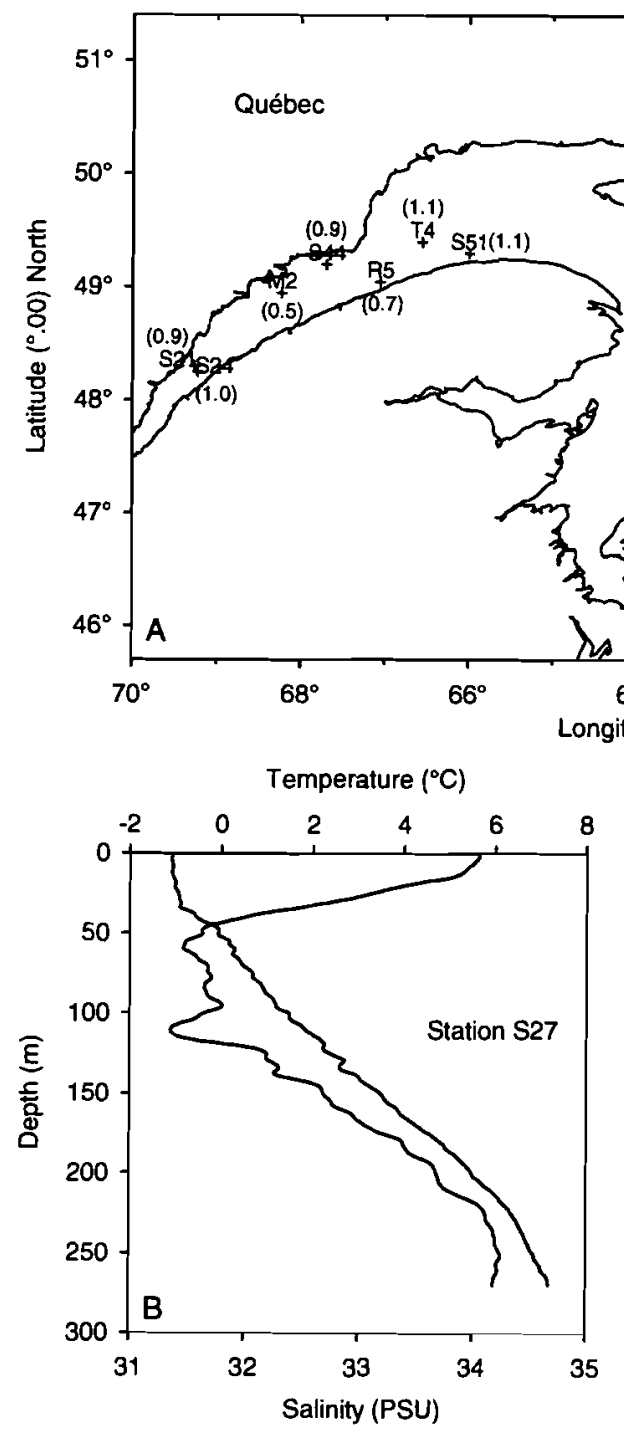

$16 \mathrm{~m}$ UV-grade quartz fibre-optic cable to an Optronic Laboratories Inc. (Orlando, FL, USA) OL-754-O-PMT scanning spectrophotometer. Measurements were made at 12 locations in the surface waters of the estuary and Gulf of the St. Lawrence (Fig. 1) in September 1996 and in June and September 1997. Vertical profiles consisted of spectral scans made at 4 depths, beginning just below the surface and at $1 \mathrm{~m}$ intervals down to $3 \mathrm{~m}$. Measurements were made as close to solar noon as possible to reduce the changes in solar irradiance associated with changing solar elevation. Immersion correction factors (ICFs) applied to the data, determined empirically following the methods outlined by Mueller \& Austin (1995), ranged between 1.6 and 1.8. Diffuse attenuation coefficients $\left(K_{\mathrm{d} \lambda}\right)$ were calculated from

$$
K_{\mathrm{d} \lambda}=\frac{\ln \left(\frac{E_{-0 \lambda}}{E_{z \lambda}}\right)}{\Delta z}
$$


where $E_{-0 \lambda}$ and $E_{z \lambda}$ are irradiances measured just below the surface and at depth $z(\mathrm{~m})$.

The $10 \%$ depth penetrations were determined from smoothed $K_{\mathrm{d} \lambda}$ values (Kuhn et al. 1999).

Water samples for DOC and chl a analysis were taken from a depth of $5 \mathrm{~m}$. Analyses for these components were made using standard protocols: the fluorometric method for chl $a$ and high-temperature catalytic oxidation for DOC. Complete details of the methods used to obtain the optics and water chemistry data are reported in Kuhn et al. (1999).

Station-averaged spectral flux at $300 \mathrm{~nm}$ was $1.1 \times$ $10^{-3} \mathrm{~W} \mathrm{~m}^{-2} \mathrm{~nm}^{-1}$ just below the surface. Detectable fluxes (greater than the instrument's noise level of $1 \times$ $10^{-5} \mathrm{~W} \mathrm{~m}^{-2} \mathrm{~nm}^{-1}$ ) just below the surface were measured at wavelengths as low as $294 \mathrm{~nm}$ (Stn T4; Fig. 1A). There was little variation in this lower wavelength limit among stations: $296 \pm 2 \mathrm{~nm}$. At $300 \mathrm{~nm}, K_{\mathrm{d}}$ values ranged from approximately 1 to $5 \mathrm{~m}^{-1}$, with corresponding $10 \%$ depth penetrations of 2.3 and $0.4 \mathrm{~m}$ (Fig. 2). At $400 \mathrm{~nm} K_{\mathrm{d}}$ varied between 0.2 and $1.4 \mathrm{~m}^{-1}$ and the $10 \%$ depth penetrations were 21 and $1.4 \mathrm{~m}$ (Fig. 2). The $10 \%$ depths were generally smallest in the estuary (Stns M2, R5, S21, S24 and S44; Fig. 1A) and became greater in the clearer waters toward, and in, the Gulf (Stns T4, S51, S73, S103, S27, S4 and S94; Fig. 1A). All values fall within the range of $10 \%$ depth penetrations presented in the review article by Booth \&

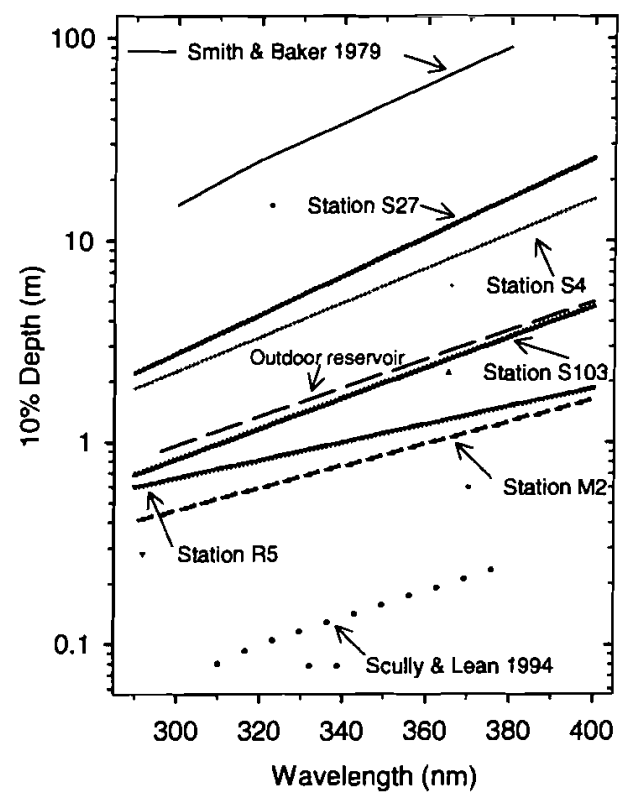

Fig. 2. $10 \%$ depth penetrations at selected stations in the estuary and Gulf of St. Lawrence. Station locations are plotted in Fig. 1A. All values fall within the range reported by Scully \& Lean (1994) for the highly UV-opaque Lake Cromwell, Québec, and by Smith \& Baker (1979) for extremely clear marine waters
Morrow (1997): at $310 \mathrm{~nm}$ a depth of $0.1 \mathrm{~m}$ was recorded by Scully \& Lean (1994) in Lake Cromwell, Québec, and values as high as $20 \mathrm{~m}$ were reported for clear ocean waters by Smith \& Baker (1979) (Fig. 2).

The lowest DOC and chl $a$ values $-0.448 \mathrm{~g} \mathrm{~m}^{-3}$ and $0.05 \mathrm{\mu g} \mathrm{l}^{-1}$, respectively-were measured at Stn S27 (sampled on 15 June 1997). The highest DOC value$3.59 \mathrm{~g} \mathrm{~m}^{-3}$ - was recorded at Stn S21 (sampled on 1 September 1997), and the highest chl $a$ value $-2.02 \mu \mathrm{g}$ $\mathrm{I}^{-1}$ - was recorded at Stn S44 (sampled on 30 August 1997) (Kuhn et al. 1999).

Spearman's correlations were used to evaluate the relationship between attenuation coefficients (290 to $400 \mathrm{~nm}$, at $10 \mathrm{~nm}$ intervals) and concentrations of chl a and DOC. For all wavelengths, DOC was more highly correlated with $K_{\mathrm{d}}$ than was chl a. The average correlation coefficient between DOC and $K_{\mathrm{d}}$ was 0.81; between chl $a$ and $K_{\mathrm{d}}, 0.73$; and between chl $a$ and DOC, 0.73 . In other marine environments, chl $a$ is highly correlated with UV attenuation (Stambler et al. 1997). In freshwater, DOC is the dominant factor in UV attenuation and chl $a$ is most often unimportant (Scully \& Lean 1994, Morris et al. 1995, Laurion et al. 1997). However, for most marine water types there is a significant autocorrelation between DOC and chl a, making it difficult to determine their respective contributions to the diffuse attenuation coefficients. However, the slopes of these relationships imply that yellow substance, and therefore DOC, is important (Kuhn et al. 1999). Because of the mixed influence chl $a$ and DOC have on UV attenuation in marine waters, seasonal changes in the relative concentrations of these parameters will significantly affect UV penetration.

These measurements indicàte that potentially harmful levels of UV radiation penetrate into the summer mixed-layer water column in the upper estuary and Gulf of St. Lawrence. Ultraviolet-A radiation (UV-A, 320 to $400 \mathrm{~nm}$ ) reaches even greater depths (Fig. 2). Thus, the early life history stages of the crustacean and fish species that are present in this shallow mixed layer may be impacted by UV radiation.

\section{EFFECTS OF UV-B ON CRUSTACEAN ZOOPLANKTON AND ICHTHYOPLANKTON}

\section{Copepod study species: Calanus finmarchicus Gunnerus}

The planktonic copepod Calanus finmarchicus is prominent in the mesozooplankton community of the Gulf of St. Lawrence and Labrador Shelf (Grainger 1963, de Lafontaine et al. 1991). C. finmarchicus females release their eggs near the surface, probably during the night and early morning, and from early 
spring through fall (Runge \& Plourde 1996). Of these eggs, 30 to $50 \%$ are present in surface waters, 0 to $5 \mathrm{~m}$ (Runge \& de Lafontaine 1996) (Fig. 1C). Larvae of redfish Sebastes spp., a commercially important stock in the north-central Gulf of St. Lawrence, ingest large numbers of the egg and naupliar stages of $C$. finmarchicus in early summer (Runge \& de Lafontaine 1996). Later in the summer, these same larvae feed on C. finmarchicus nauplii and copepodites (J. A. Runge \& Y. de Lafontaine unpubl. obs.). Although never rigorously studied, the contribution of $C$. finmarchicus to the diet of larval cod spawned in the Gulf of St. Lawrence and on the Labrador Shelf is assumed to be similar in importance to the role of $C$. finmarchicus in the diet of arctonorwegian cod larvae in Norwegian coastal waters. This C. finmarchicus-redfish (and presumably cod) interaction in the northern Gulf of St. Lawrence occurs in the shallow surface mixed layer.

\section{Ichthyoplankton study species: Atlantic cod}

The reproductive season for Atlantic cod in the Gulf of St. Lawrence begins early in the spring (April) and continues through mid-summer (July) (Ouellet et al. 1997). Spawning occurs in deep water $(>200 \mathrm{~m})$, and cod eggs, which are typically positively buoyant, ascend to the surface mixed layer over a period of 2 to $10 \mathrm{~d}$ (Solemdal \& Sundby 1981, Anderson \& de Young 1995, Ouellet 1997). Cod eggs are present in the 0 to $25 \mathrm{~m}$ depth stratum off the Newfoundland Shelf (Anderson \& de Young 1995), off Greenland and Labrador (Brander 1994), on southern Georges Bank (Lough et al. 1996) and in the northern Gulf of St. Lawrence (Ouellet 1997) (Fig. 1C). The specific proportion of the egg population present in this surface layer cannot be definitively quantified since the vertical distribution of cod eggs is dependent upon a number of variable and interacting factors (egg buoyancy, meteorologic and hydrographic conditions, etc.). Nonetheless, when wind speed is low, the highest egg concentrations are observed in the upper 0 to $10 \mathrm{~m}$ of the water column (Solemdal \& Sundby 1981). The early larval stages are also typically present, and often even closer to the surface (Anderson \& de Young 1995).

\section{Outdoor exposure experiments}

As a first step toward evaluating the potential effects of UV on Calanus finmarchicus and cod, we conducted a series of experiments in which eggs of both species were incubated under the sun, with and without the UV-B and/or UV-A wavebands. We wished to determine whether current levels of UV radiation at the ocean surface would have a detrimental effect on the early life stages of these species.

Eggs were placed into quartz tubes (approximately 50 tube $^{-1}$ for Calanus finmarchicus and 100 tube $^{-1}$ for cod) and immersed in a reservoir containing filtered sea water and located on the grounds of the MauriceLamontagne Institute in Mont-Joli, Québec, Canada (MLI, 48 $38^{\prime} 25.9^{\prime \prime} \mathrm{N}, 68^{\circ} 09^{\prime} 21.0^{\prime} \mathrm{W}$ ). UV penetration into the experimental reservoir was similar to that observed in estuarine waters of this region, but lower than that in the clearer waters of the Gulf of St. Lawrence (Fig. 2). Tubes were suspended underwater, at depths of 2 and $60 \mathrm{~cm}$ for $C$. finmarchicus and 3 and $50 \mathrm{~cm}$ for cod, under 3 light regimes. The first was UV-B + UV-A + PAR (photosynthetically active radiation, 400 to $700 \mathrm{~nm}$ ); eggs in this treatment (Quartz) incubated in quartz tubes - were exposed to the complete solar spectrum. The second was UV-A + PAR; in this treatment (Mylar), UV-B was excluded by wrapping the quartz tubes with Dupont's $0.05 \mathrm{~mm}$ thick Mylar D ${ }^{\mathrm{TM}}$. The third was a PAR-only treatment (OP-2); UV-A and UV-B were eliminated by placing the quartz tubes under a $3 \mathrm{~mm}$ thick piece of the acrylic sheet material OP-2 ${ }^{\mathrm{TM}}$ (Cyro Industries). The spectral irradiance measured under these materials verified their effectiveness in producing the desired exposure treatment (Béland et al. 1999, Alonso Rodriguez et al. 2000). There were a total of 42 quartz tubes in each experiment: 7 for each light regime at each of the 2 depths. Incubations, conducted during the summers of 1996 and 1997, were 2 to $3 \mathrm{~d}$ long for $C$. finmarchicus and $10 \mathrm{~d}$ long for cod. At these temperatures, the embryonic period of C. finmarchicus is approximately $2 \mathrm{~d}$, while that for cod is $14 \mathrm{~d}$.

For the experiments with Calanus finmarchicus, the percentage of eggs that had hatched at the end of each experiment was calculated for each incubation tube. Cod eggs become opaque shortly after dying, making it possible to census mortality by visual inspection. Thus, the number of dead eggs in each of the incubation tubes was counted daily throughout each experiment. In order to minimize handling stress, dead eggs were not removed from the tubes during the experiment. Cumulative mortality of cod eggs was derived from the daily counts of dead eggs in each tube. Complete details of the methods employed in these experiments are reported in Alonso Rodriguez et al. (2000) for C. finmarchicus and in Béland et al. (1999) for cod.

Calanus finmarchicus. C. finmarchicus eggs were negatively affected by ambient levels of solar UV radiation (Quartz and Mylar vs OP-2 and Dark treatments) (Fig. 3). Further, percent hatching in eggs exposed to both UV-B and UV-A (Quartz) was not significantly lower than that in eggs exposed to UV-A only (OP-2): under natural sunlight, UV-A radiation appeared to be 


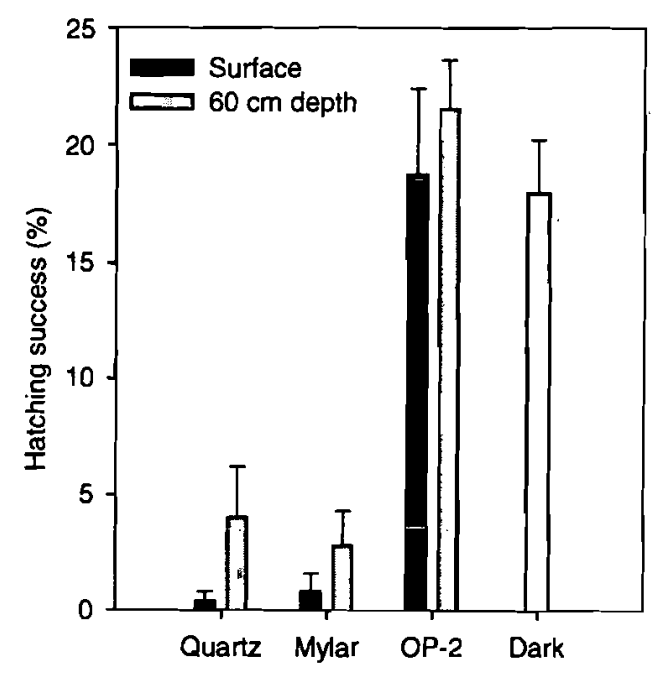

Fig. 3. Calanus finmarchicus. Hatching success (mean $\pm \mathrm{SE}$ ) of eggs incubated outside the Maurice-Lamontagne Institute (MLI), Mont-Joli, Québec, Canada $\left(48^{\circ} 38^{\prime} 25.9^{\prime \prime} \mathrm{N}\right.$, $68^{\circ} 09^{\prime} 21.0^{\prime \prime} \mathrm{W}$ ). Incubations were carried out at 2 depths: just below the surface and at $60 \mathrm{~cm}$. Eggs were exposed to 3 light regimes: (1) Quartz, UV-B + UV-A + PAR, eggs in this treatment-incubated in quartz tubes--were exposed to the complete solar spectrum; (2) Mylar, UV-A + PAR, in this treatment UV-B was excluded by wrapping the quartz tubes with Dupont's $0.05 \mathrm{~mm}$ thick type D Mylar ${ }^{\mathrm{TM}}$; (3) OP-2, PAR-only, in this treatment UV-A and UV-B were eliminated by placing the quartz tubes under a $3 \mathrm{~mm}$ thick piece of the acrylic sheet material OP-2 ${ }^{\mathrm{TM}}$ (Cyro Industries). Control groups (Dark) were incubated in quartz tubes wrapped with aluminum foil

more detrimental to $C$. finmarchicus embryos than was UV-B (Fig. 3). There was no consistent statistically discernible effect of incubation depth in these experiments (but see Alonso Rodriguez et al. 2000 for specific exceptions). These results were consistent across 3 independent experiments (only 1 of which is presented here), and were statistically discernible (Alonso Rodriguez et al. 2000).

It is possible that the low percent hatching in these 2 treatments, the high variability among replicates, and the low statistical power resulting from several missing replicates masked any difference in their response to UV-B exposure. Further, the Mylar material used in these experiments transmits some energy at the UV-B/ UV-A transition (13\% transmission at $315 \mathrm{~nm} ; 49 \%$ at $320 \mathrm{~nm}$ ), so the eggs in the Mylar treatments were exposed to some UV-B radiation. Given the high impact weightings for exposures at these wavelengths (see below), this amount of energy may have been enough to kill the eggs. It is possible, therefore, that wavelengths at the UV-B/UV-A transition are at least partly responsible for the low percent hatching in the Quartz and Mylar treatments of our experiments. The boundaries of the UV-B and UV-A wavebands have been established based upon ozone absorption profiles
(Lubin \& Frederick 1991). Given the variety of biological and biochemical effects induced by UV radiation, all of them wavelength-dependent, it is not always appropriate, nor biologically relevant, to be bounded by these arbitrary limits.

Some marine copepods are negatively affected by current levels of UV-B radiation (Thomson 1986). UV-Binduced naupliar mortality, reduced survival and fecundity in females, and sex ratio shifts have all been reported (Karanas et al. 1979, 1981, Chalker-Scott 1995, Naganuma et al. 1997). Further, UV-B-induced damage to the DNA of crustacean zooplankton has been detected in samples collected from depths of up to $20 \mathrm{~m}$ (Malloy et al. 1997). This is the first investigation of the effects of UV radiation on the early life stages of Calanus finmarchicus; few data exist on UVinduced egg mortality in marine copepods with which to compare our results. Nonetheless, these screening experiments, and the results presented below from higher spectral resolution treatments, support the contention that UV is detrimental.

It is also possible that eggs were killed by longer wavelengths of UV-A radiation. The effect of UV-A radiation on biological systems remains unclear (Sutherland et al. 1992). While its role in DNA photorepair has been well documented (Sutherland 1981, Hearst 1995, Mitani et al. 1996), fewer studies have demonstrated its deleterious effects on aquatic organisms. However, UV-A radiation inhibits photosynthesis in Antarctic diatoms and dinoflagellates, and in freshwater algae (Cullen et al. 1992, Bothwell et al. 1994). Furthermore, UV-A radiation induced a transitory decrease in the metabolic rate of the cichlid fish Cichlasoma nigrofasciatum (Winckler \& Fidhiany 1996), a lower hatching success in embryos of the Japanese medaka Oryzias latipes (Bass \& Sistrun 1997) as well as increased mortality in eggs of the yellow perch Perca flavescens (Williamson et al. 1997) and in the freshwater copepod Boeckella gracilipes (Zagarese et al. 1997). Unlike UV-B, UV-A does not induce damage through direct absorption of photons by the DNA molecule (Beer et al. 1993). Although wavelengths as long as $365 \mathrm{~nm}$ induce detectable levels of cyclobutane pyrimidine dimers (Ahmed \& Setlow 1993), 1 of the main UV-B photoproducts in the DNA molecule (Hearst 1995), the action spectrum for DNA damage indicates that the relative biological response to wavelengths beyond $310 \mathrm{~nm}$ is negligible (Setlow 1974).

UV-A radiation is absorbed by organic molecules other than DNA, such as proteins, lipids and RNA. The dissipation of the absorbed energy via photochemical reactions generates a variety of by-products (hydroxyl radicals, superoxide, hydrogen peroxide and singletstate oxygen) which can accumulate and cause significant oxidative damage to cross-link membrane lipids 
and other cellular components (Lesser \& Shick 1989 and references therein, Beer et al. 1993). Pigments such as melanin or the carotenoids are known to act as free-radical scavengers and energy transducers (Hessen 1994), but Calanus finmarchicus eggs are unpigmented. Moreover, interaction between UV and dissolved organic matter (DOM) present in the water can also produce reactive oxygen transients which subsequently have cytotoxic effects (Zepp et al. 1987). This mechanism of damage occurs over a relatively longer time frame than direct damage to DNA since it results from cumulative physiological stress. This might explain why Kouwenberg et al. (1999b) did not find a UV-A effect: in those experiments, $C$. finmarchicus eggs were exposed to only $1 \mathrm{~h} \mathrm{~d}^{-1}$ of UV-A (see below). Further experiments are required to resolve the issues surrounding UV-B versus UV-A effects.

Atlantic cod. Cod embryos exposed to UV-B radiation (Quartz treatment) exhibited a higher rate of mortality, and greater cumulative mortality, than those shielded from UV-B (Mylar and OP-2 treatments) (Fig. 4). These results were consistent across 4 experiments (only 1 of which is presented here), and were statistically discernible (Béland et al. 1999). UV-Binduced mortality at the surface was virtually $100 \%$, but that at $50 \mathrm{~cm}$ was negligible (at least in this experiment-but see Béland et al. 1999).

Mortality of yellow perch Perca flavescens eggs, incubated in situ at various depths and under spectral

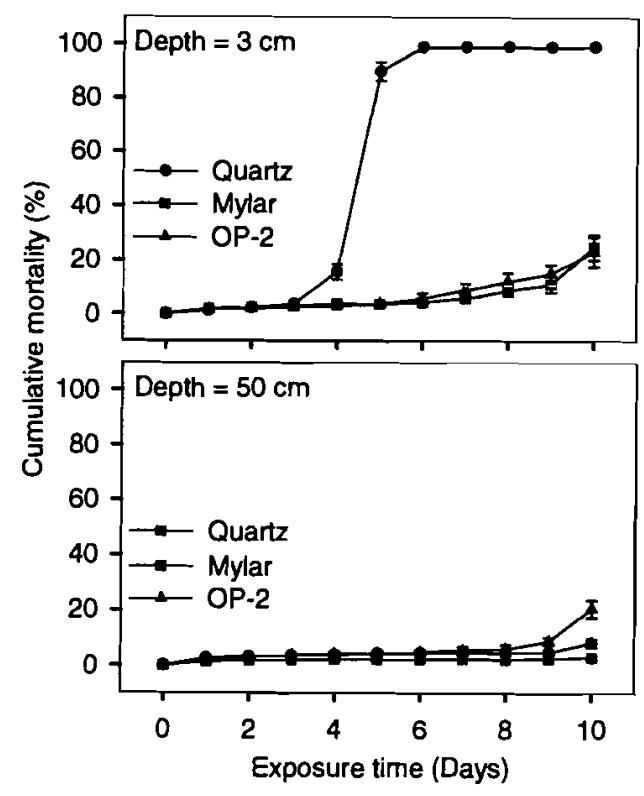

Fig. 4. Gadus morhua. Percent cumulative mortality (mean \pm $\mathrm{SE}$ ) in Atlantic cod eggs incubated outside the MLI. Incubations were carried out at 2 depths: just below the surface and at $50 \mathrm{~cm}$. Eggs were exposed to the same 3 light regimes described in Fig. 3 exposure treatments similar to those reported here, was very high (>95\%), even at depths up to $0.8 \mathrm{~m}$ (Williamson et al. 1997). Observations from the few other studies on UV-B-induced mortality in fish eggs are also consistent with our results (Marinaro \& Bernard 1966, Pommeranz 1974, Hunter et al. 1982).

Negative effects of UV-A on fishes have been documented (see the preceding section). Nonetheless, cod eggs were not negatively affected by exposure to UVA radiation in our experiments: there were no clear differences in mortality in the UV-A+PAR (Mylar) treatment relative to the PAR-only (OP-2) treatment (Fig. 4). This result is consistent with that reported from higher spectral resolution experiments on UV-induced mortality in cod eggs: there was no clear negative effect of UV-A (see below and Kouwenberg et al. 1999a). As was the case for Calanus finmarchicus, further experiments on the effects of UV-A and visible light - both in inducing mortality and with respect to the balance between photodamage and photorepair - are required to resolve these issues.

The experiments reported here indicate that Atlantic cod eggs-at least those present in the first $0.5 \mathrm{~m}$ of the water column-are susceptible to UV-B radiation. However, the $10 \%$ depths for UV penetration in the outdoor reservoir were less than those for regions of the Gulf of St. Lawrence where cod spawn (Fig. 2, and see Béland et al. 1999). This suggests that the impact of UV-B reported here is an underestimate of that which would be observed in the wild. This conclusion, however, must be carefully qualified.

Although the available information on the vertical distribution of cod eggs in this region is limited, it appears that most are not present in the upper $4 \mathrm{~m}$ of the water column (Ouellet 1997). Even if most cod eggs were present in the 0 to $15 \mathrm{~m}$ mixed layer of the northern Gulf of St. Lawrence water column, they would be in circulation and their daily residence time in the upper $4 \mathrm{~m}$ would depend upon meteorological and hydrographic conditions (among other things-see Solemdal \& Sundby 1981). Short residence times, which appear likely, would further reduce the population-level impact of UV-B on cod eggs. These issues are taken up again in the simulation model section below.

\section{Solar simulator experiments}

The outdoor experiments described above allowed an assessment of whether exposure to current levels of UV-B, UV-A or PAR had a detrimental effect on Calanus finmarchicus or cod eggs. However, the conclusions that can be drawn from broad-band screening experiments such as these are limited, and they cannot 
be used to make predictions about impacts that might occur under different conditions of spectral quality and intensity.

A number of factors make it difficult to predict the biological effect of UV-B radiation on aquatic organisms. For example, (1) the spectral composition and intensity of light reaching the Earth's surface are highly variable, being affected by weather conditions, the thickness of the ozone layer, and air pollution, among other things (Varotsos et al. 1994, Graedel \& Crutzen 1995, Madronich et al. 1995, Németh et al. 1996). This variability is both spatial and temporal. (2) The underwater light field is further affected by the wavelength-specific diffuse attenuation coefficients of water bodies, themselves highly variable, geographically, seasonally and annually (Piazena \& Häder 1994, Laurion et al. 1997). (3) Photon absorption by the DNA molecule, by proteins, by tissues and by whole organisms is strongly wavelength-dependent, dropping off steeply above $300 \mathrm{~nm}$ (see the data reported by e.g. Setlow 1974, Coohil 1991, Cullen \& Neale 1997). Since the biological effectiveness of UV photons is inversely related to wavelength, and short-wave photons are strongly absorbed by organic molecules and sea water, relatively small changes in UV-B irradiance can lead to large changes in biological effect. (4) Ozone layer depletion will not affect the entire UV-B waveband equally. Rather, increases in UV-B associated with a thinning ozone layer will be mainly restricted to the 295 to $312 \mathrm{~nm}$ waveband: the most damaging wavelengths (Kerr \& McElroy 1993, Graedel \& Crutzen 1995, Madronich et al. 1995). Following from this, any attempt to assess the impact of UV-B radiation on planktonic marine organisms requires that the wavelength-dependent biological effect of UV-B photons be known. That is, a relevant BWF-like those presented here for Calanus finmarchicus and cod egg mortality (see below) - must be available (Cullen \& Neale 1997 provide a thorough presentation of this issue).

The goals of the solar simulator (SS) experiments were: (1) to evaluate the effect of UV radiation on mortality in the eggs of Calanus finmarchicus and Atlantic cod, with a higher degree of spectral resolution and irradiance control than is possible with screening experiments; (2) to generate dose-response relationships and test the principle of reciprocity, which states that the UV-B-induced mortality effect on eggs will be dose but not dose rate dependent; (3) to derive BWFs for the effect of UV on mortality in C. finmarchicus and Atlantic cod eggs; (4) to evaluate DNA damage as a function of spectral exposure; and (5) to present an assessment of the potential direct impact of solar UV radiation on the early life stages of $C$. finmarchicus and cod in the subarctic marine ecosystems of eastern Canada.
Calanus finmarchicus and cod eggs were irradiated under a SS consisting of two $1 \mathrm{~kW}$ Xenon-arc-lamps. The spectral output of these lamps was adjusted using various combinations of optical filters to produce a mean $( \pm \mathrm{SD})$ integrated irradiance of $450 \pm 197 \mathrm{~W} \mathrm{~m}^{-2}$ (280 to $800 \mathrm{~nm}$ ). This approximated the irradiance delivered to the Earth's surface outside the MLI during a sunny summer's day $\left(429 \pm 164 \mathrm{~W} \mathrm{~m}^{-2}\right.$-this is a mean of 3 measurements made at 10:00, 12:00 and 15:00 $\mathrm{h}$ on the same day). However, as compared to sunlight, the spectral irradiance delivered by the SS was higher in the UV-B region and lower in the visible waveband ( 400 to $700 \mathrm{~nm}$, Kouwenberg et al. 1999a, their Fig. 1). Full details of the optical characteristics of this SS are available in Kouwenberg et al. (1999a).

Eggs were irradiated in glass incubation tubes immersed in a circular basin filled with re-circulating filtered seawater at $6^{\circ} \mathrm{C}$ and a salinity of $28 \pm 1$ psu. This design ensured that all of the eggs in the experiment were exposed to similar conditions. The bottom of the incubation basin was fitted with a polyethylene holder which contained a slot for each of 34 incubation tubes. The holder was designed so that it remained in the same position and orientation under the SS during each exposure. Each incubation tube was covered with a $25 \times 25 \mathrm{~mm}$ quartz-substrate long-pass filter. The filters used were Schott WG280, WG295, WG305, WG312, WG335, WG360 and GG400, for which the $50 \%$ cut-off wavelength (nm) is approximately that specified. Spectral transmission curves for the filters used are reported in Kouwenberg et al. (1999a, their Fig. 2). There were 5 replicate tubes for each cut-off filter treatment except for WG360, which had 4 . Spectral irradiance, $E(\lambda)$ (in $\mathrm{W} \mathrm{m}^{-2} \mathrm{~nm}^{-1}$ ), was measured (using the Optronic Laboratories OL-754-O-PMT) at $1 \mathrm{~nm}$ intervals under each of the cut-off filters at all 34 tube positions in the incubator.

DNA-weighted biologically effective irradiance delivered to the tubes in the WG280, 295, 305, 312 and 335 treatments-calculated as the mean $( \pm$ SE) of all the tubes in each of these spectral exposure treatments - was: $12.62 \pm 5.4,4.55 \pm 2.0,1.55 \pm 0.8,0.07 \pm 0.04$, and $0.03 \pm 0.01 \mathrm{~W} \mathrm{~m}^{-2}$, respectively. These dose rates were weighted using the Setlow (1974) DNA action spectrum (interpolated linearly in log space), normalized to 1 at $300 \mathrm{~nm}$, and for which weightings were set to 0 for wavelengths $>315 \mathrm{~nm}$.

Calanus finmarchicus eggs were irradiated under the SS for $1 \mathrm{~h}$ on 1 day and for $0.5 \mathrm{~h}$ on another day $(2$ different experiments with the same dose rate but a different total dose). After the exposures, eggs were maintained on a $12 \mathrm{~h}$ light: $12 \mathrm{~h}$ dark photoperiod. Control groups (4 to 5 incubation tubes), drawn from the same population of females but not exposed to the SS, were maintained on the same photoperiod. Cod eggs 
were typically irradiated for $7 \mathrm{~d}\left(2 \mathrm{~h} \mathrm{~d}^{-1}\right)$, until just prior to hatching. In the $C$. finmarchicus experiments, healthy nauplii (as a percent of the initial number of eggs placed into each tube) were enumerated at the end of each experiment. For cod, incubation tubes were examined each morning for egg viability, and dead eggs - which sink and quickly become opaquewere removed and counted. Complete details of the methods employed in the SS experiments are reported in Kouwenberg et al. $(1999 a$, b).

Wavelength-dependent mortality in Calanus finmarchicus and cod eggs. UV-B radiation, particularly in the 280 to $312 \mathrm{~nm}$ waveband, had a strong negative impact on the survival of $C$. finmarchicus eggs, even over short exposure times (Fig. 5) and at low total doses. At the shorter wavelengths $(<305 \mathrm{~nm})$ UV-Binduced mortality was strongly dependent upon cumulative dose (Kouwenberg et al. 1999b). The mortality effect was less pronounced in the $312 \mathrm{~nm}$ treatment, and there was no effect in the 335, 360 and $400 \mathrm{~nm}$ treatment groups (Fig. 5). The spectral resolutions of these results are the highest so far generated for a copepod. Nonetheless, similar dose-dependent effects have been reported for Acartia clausii (Karanas et al. 1979) irradiated under Westinghouse FS40 sunlamps and for several other species (Karanas et al. 1979, 1981, Thomson 1986, Dey et al. 1988, Naganuma et al. 1997).

UV-B radiation, particularly in the 280 to $312 \mathrm{~nm}$ waveband, had a strong negative impact on the survival of Atlantic cod eggs (Fig. 6). This is consistent

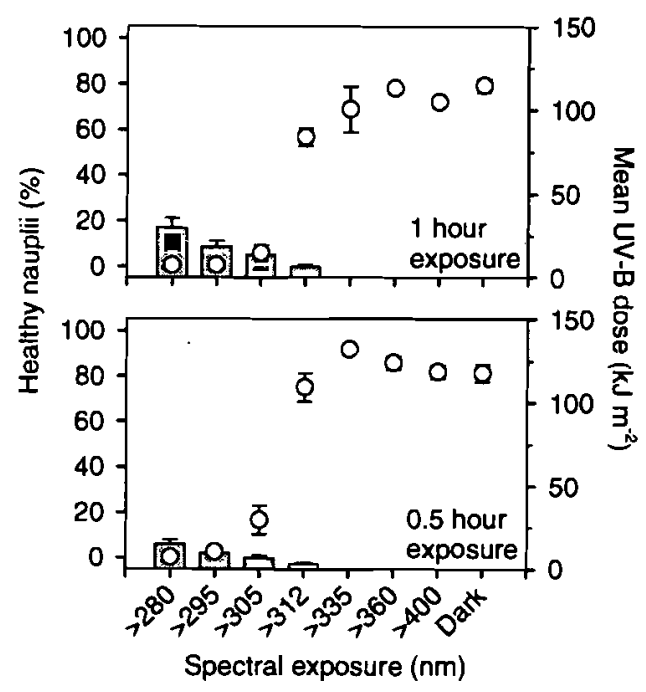

Fig. 5. Calanus finmarchicus. Survival of eggs exposed to various spectral wavebands. Open circles are the mean $( \pm S E)$ proportion of healthy nauplii from eggs exposed to radiation greater than the specified cut-off wavelength; filled bars represent the mean $( \pm S E$ ) UV-B dose delivered under each of the spectral exposure treatments; 2 exposure durations are presented, as noted in each panel

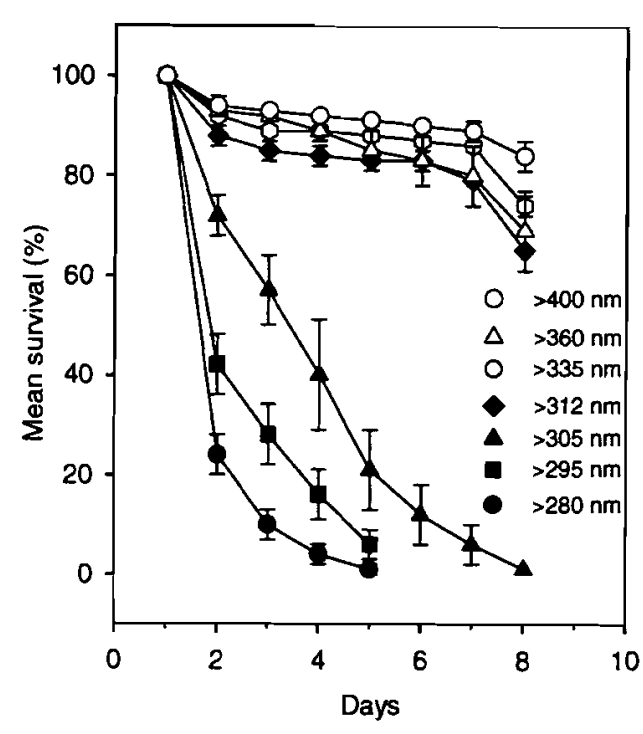

Fig. 6. Gadus morhua. Mean ( $\pm \mathrm{SE}$ ) survival of Atlantic cod eggs exposed to various spectral wavebands, without photorepair between exposures. Each curve represents the mortality induced by exposure to radiation greater than the cutoff wavelength indicated. Open symbols denote treatments that received UV-A and visible light, or visible light only. Filled symbols denote treatments that received radiation in the UV-B+UV-A+visible wavebands

with observations on several other species (Marinaro \& Bernard 1966, Pommeranz 1974, Hunter et al. 1982, Williamson et al. 1997), although these earlier studies do not provide the same spectral resolution. There was also evidence suggesting the presence of photorepair mechanisms in cod eggs (Kouwenberg et al. 1999a). Remediating effects of photorepair on UV-B-induced mortality, and DNA damage, have been reported for northern anchovy Engraulis mordax larvae (Kaup \& Hunter 1981, Vetter et al. 1999). Mitchell et al. (1993) reported on DNA photorepair in UV-B exposed platyfish Xiphophorus variatus and Mitani et al. (1996) observed that exposure to UV-A and blue light induced the production of cyclobutane pyrimidine dimer photolyase (involved in the repair of UV-Binduced DNA damage) in cultured cells of the goldfish Carassius auratus. Similar results on photorepair have been reported by Vetter et al. (1999).

DNA damage. Formation of cyclobutane pyrimidine dimers (CPDs) in DNA is one of the most common results of exposure to UV-B radiation. The formation of CPDs, and their repair, has been well-studied in fish cell lines, fish embryos and fish skin (Achey et al. 1979, Shima et al. 1981, Regan et al. 1983, Shima \& Setlow 1984, Applegate \& Ley 1988, Ahmed \& Setlow 1993). Since the concentration of CPDs in an organism's DNA is directly related to UV-B exposure, they are potentially useful as UV-B-specific indicators of exposure in wild populations of fish larvae (Vetter et al. 1999). 
Thus, we undertook to describe the wavelength-specific effect of UV-B exposure on DNA damage in Calanus finmarchicus and cod eggs.

Calanus finmarchicus and cod eggs were irradiated under the SS (as above) for $1 \mathrm{~h}$, placed in the dark and preserved in anhydrous alcohol. This ensured that there was no time to repair any UV-induced damage to the DNA molecule. A control group was incubated under the SS in the dark (tubes were wrapped in aluminum foil). Total nucleic acids were extracted from eggs, and the DNA was purified and eluted into TE buffer. DNA concentration in each sample was determined with a DNA fluorometer. CPDs were measured using a chemiluminescent immunoblot assay which is thoroughly described in Vetter et al. (1999).

UV-induced damage - as represented by CPD concentration per mb (megabase) of DNA - to the DNA in Calanus finmarchicus and cod eggs was highest in the WG280, WG295, WG305 and WG312 exposure treatments (Fig. 7). These were all significantly different from the other exposure treatments, and from the dark controls (Bonferroni $t$-test, $\mathrm{p}<0.05$ ). CPD concentration in the UV-A exposure treatments was not significantly different from that in the dark controls (Fig. 7). These data indicate that $C$. finmarchicus eggs are significantly more susceptible to UV-B-induced DNA damage than are cod eggs. This likely reflects differences in the relative rates of damage and repair in these 2 organisms.

There have been a number of studies on UV-induced damage and photorepair in fishes (cited above). None, however, have evaluated the wavelength-specific effect of UV on the early life stages of crustacean zooplankton, nor of fishes. Thus, these data will be used to develop BWFs for the evaluation of DNA damage in the eggs of these 2 species (Browman et al. unpubl.). Such BWFs can be used to assess DNA damage to egg

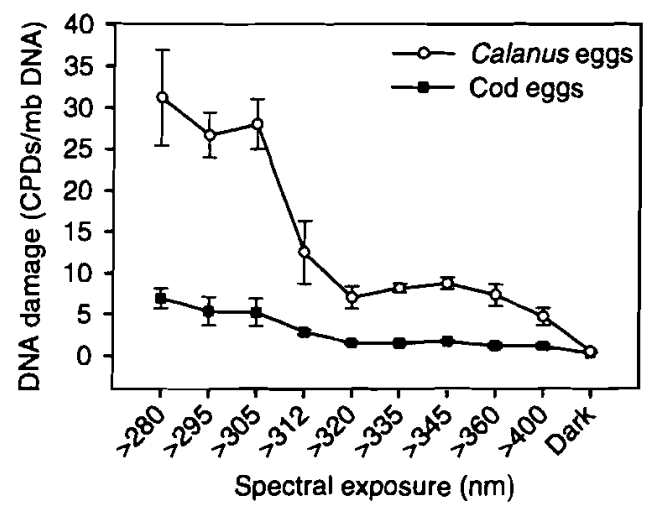

Fig. 7. Mean ( \pm SE) DNA damage in Calanus finmarchicus and Atlantic cod Gadus morhua eggs exposed to various spectral wavebands at the same dose rate and total dose populations exposed to sunlight, allowing a more direct evaluation of possible UV-B impacts to wild populations (sensu Vetter et al. 1999).

Biological weighting functions. Data on the differential survival of Calanus finmarchicus and cod eggs exposed to varying amounts of UV radiation were fit to an exponential model the final form of which is:

$$
\frac{\operatorname{Egg}(d)}{\operatorname{Egg}(0)}=\mathrm{e}^{-\left(H^{*}+M \cdot T\right)}
$$

where $\mathrm{Egg}(0)$ is the number of live eggs in any 1 incubation tube on Day 0, $\mathrm{Egg}(d)$ is the number of live eggs in that tube on Day $d_{1} H^{*}$ (dimensionless) is the sample's biologically weighted radiant exposure, $M\left(\mathrm{~s}^{-1}\right)$ is a fitted parameter for non irradiance-dependent mortality and $T(\mathrm{~s})$ is the total length of the experiment. Data generated in the SS experiments provided the number of $C$. finmarchicus or cod eggs surviving in each of the 34 treatment tubes for each day of the experiment, the corresponding spectral irradiance $(250$ to $800 \mathrm{~nm}$ ) for that tube's position (and cut-off filter) under the SS, and the duration of the daily exposure. The analysis produces a weighting for each wavelength: it is not restricted to UV-B. Further, results from every tube-and not the mean of the 4 or 5 tubes from each spectral exposure treatment-are included in the analysis. Full details of the BWF analysis, and the complete set of equations, are reported in Kouwenberg et al. (1999a).

The BWF for UV-induced mortality in Calanus finmarchicus eggs exhibits a typically steep decline against wavelength: UV impact is more than 2 orders of magnitude higher at 290 than at $320 \mathrm{~nm}$ (Fig. 8A). The scenario is similar for cod eggs: UV-induced mortality is almost 2 orders of magnitude higher at 300 than at $320 \mathrm{~nm}$ (Fig. 8B). Based upon these weightings, C. finmarchicus eggs appear to be significantly more sensitive to UV exposure than are cod eggs (compare the 2 BWFs in Fig. 8). This is consistent with the DNA results presented in the previous section.

The wavelength-specific sensitivity of UV-induced mortality in Calanus finmarchicus and cod eggs, as defined in the BWFs, exhibits a slope consistent with that of the DNA action spectrum through $310 \mathrm{~nm}$ (Setlow 1974) (Fig. 8A,B). Further, the wavelength weightings of the BWFs are consistent with the wavelengthdependence of DNA damage reported in the preceding section. Following from this, it seems likely that UV-induced mortality in C. finmarchicus and cod eggs results from DNA damage which, if not repaired, causes mortal errors in embryogenesis and pattern formation. Weightings in the UV-A waveband were essentially nonexistent for both BWFs (Fig. 8).

Hunter et al. (1981) related weighted UV-B exposure to the survival of northern anchovy eggs and larvae 

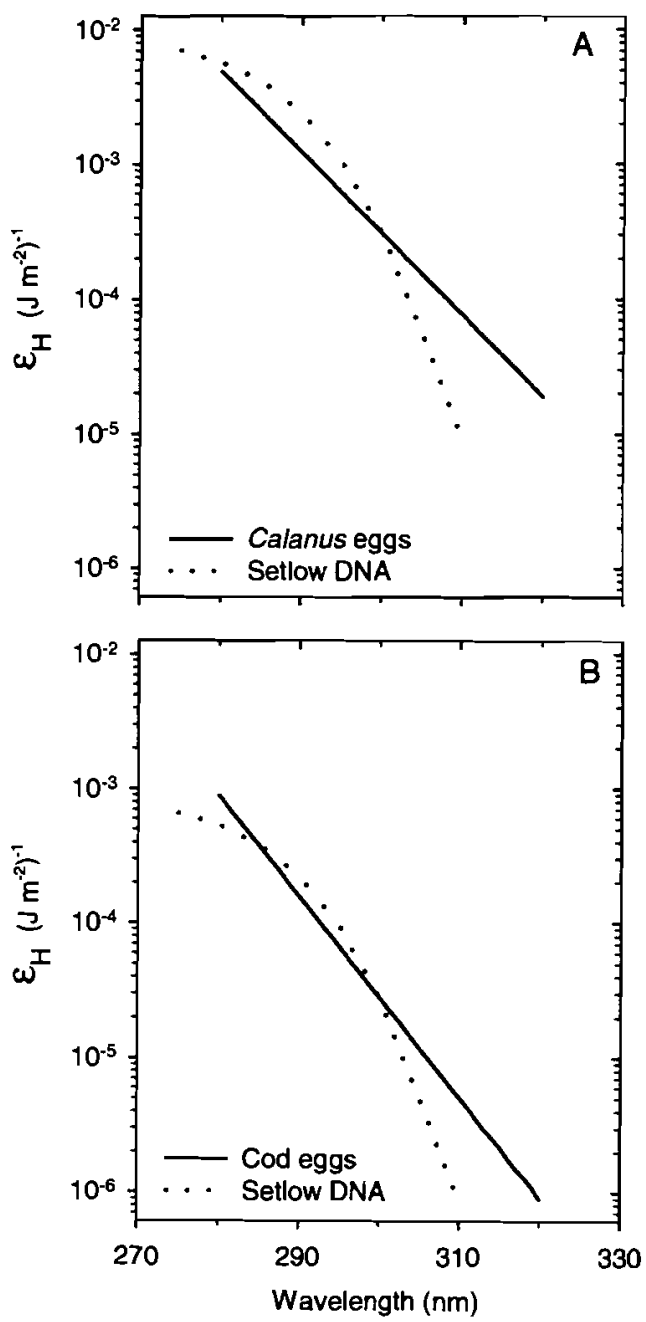

Fig. 8. (A) Biological weighting function (BWF) for egg mortality in Calanus finmarchicus (solid line). (B) BWF for egg mortality in Atlantic cod Gadus morhua (solid line). In both panels, the wavelength-dependence of damage to the naked DNA molecule (data drawn from Setlow 1974) is superimposed as a dotted line. The Setlow curve was normalized against the BWF value at $300 \mathrm{~nm}$ for ease of comparison

using several UV-B action spectra. They found that survival was best predicted when the UV-B exposure was weighted by the Setlow (1974) DNA action spectrum: this represents the first attempt to apply a BWF to UV-B-induced mortality in ichthyoplankton. BWFs such as those used by Hunter et al. (1981) yield only relative predictions-they tell us how much more (or less) mortality there will be for one spectral exposure versus another. The BWFs reported here for Calanus finmarchicus and cod eggs were derived from the mortality response itself, as opposed to being chosen as the best predictor of relative mortality. Consequently, the weightings are in absolute units $\left(\mathrm{J} \mathrm{m}^{-2}\right)^{-1}$. This allows differentiation of biological responses with the same spectral shape but for which the level of response is different (e.g. the DNA damage results presented in Fig. 7). The Hunter et al. (1981) approach would not allow for such a differentiation. As a result, egg mortality (in absolute terms) resulting from any given exposure (associated, for example, with different environmental conditions, such as ozone thinning) can be predicted using Eq. (2) (see 'Predictions of UV-induced mortality in Calanus finmarchicus and cod'). To the best of our knowledge, these are the first such BWFs generated for crustacean zooplankton or ichthyoplankton.

Reciprocity. One of the more important fundamental assumptions for construction of an accurate dosedependent BWF is the principle of reciprocity (De Gruijl et al. 1986, Coohill 1991, Buma et al. 1997, Cullen \& Neale 1997). In the context of a UV-B exposure experiment, reciprocity holds if the effect of cumulative dose is the same regardless of the dose rate at which it was delivered. If reciprocity fails, a short intense exposure would result in a different effect than a long weak exposure to the same cumulative dose. In this latter case, evaluations of effect versus cumulative exposure (i.e. dose-dependence) cannot be applied outside the conditions (i.e. time scales) under which they were generated, and BWFs derived from such results would be less reliable and of more limited use. The principle of reciprocity has not often been rigorously evaluated and, when it has, the results have been inconsistent (see references cited above). Nonetheless, there was no discernible effect of dose rate on hatching of Calanus finmarchicus eggs exposed to 3 different cumulative doses each delivered at 3 different dose rates (Browman et al. unpubl.): reciprocity held. In an analogous experiment with cod eggs, reciprocity also held (see Kouwenberg et al. 1999a, their Fig. 4). These radiative conditions were the same as those delivered in the experiments used to derive the BWFs. Further, reciprocity held despite the fact that the eggs were incubated under fluorescent lamps in between UV exposures, i.e., they were allowed to photorepair. Thus, the BWFs for C. finmarchicus and cod presented here can reasonably be applied to quantify the wavelength-specific impact of UV on the eggs of these species.

To our knowledge, Hunter et al. $(1981,1982)$ present the only other assessment of the reciprocity principle for a marine fish. For northern anchovy larvae, and under relatively broad dose/dose rate exposures, reciprocity did not hold. The reasons for this inconsistency are unknown. However, one possibility is the difference in the relative duration of intense UV-B exposures versus the time for repair. To the extent that repair dominates damage, reciprocity fails. When damage dominates, repair processes will not significantly compromise reciprocity. It is possible that the experi- 
ments reported here were generally consistent with reciprocity because the duration of exposure was relatively short-and so damage was dominant-while those of Hunter et al, $(1981,1982)$ were longer and less intense-and so repair was dominant. In evaluations of reciprocity, it is important to acknowledge that experiments conducted on different time scales may yield significantly different results.

\section{ECOLOGICAL CONTEXT}

\section{Direct effects of $\mathrm{UV}$ radiation}

Calanus finmarchicus. The results presented here indicate that $C$. finmarchicus may be sensitive to variation in incident $U V$ radiation in subarctic regions of the northwest Atlantic Ocean, including the Gulf of St. Lawrence and Labrador Shelf, where the cold intermediate layer sits just under the sea surface in early summer. In these regions, $C$. finmarchicus eggs, probably spawned near the surface at night or in the early morning (Runge \& Plourde 1996), are constrained to develop in the warm surface waters above the sharp thermocline that typically commences at a depth of 10 to $15 \mathrm{~m}$. Observations of $C$. finmarchicus egg distribution in the Laurentian channel show the majority of eggs residing in the surface layer (above 5 to $10 \mathrm{~m}$ ) during daytime, where they hatch into the first naupliar stage 1 to $2 \mathrm{~d}$ after maternal release (depending upon ambient temperature: McLaren et al. 1988). Because C. finmarchicus eggs are negatively buoyant (Marshall \& Orr 1955), those released in the cold intermediate layer ( 20 to 50 $\mathrm{m}$ ), or those that sink into it from above, probably never return to the surface mixed layer. We hypothesize that these eggs are likely lost to the population (as well as to larval fish predators) because their development time in this cold water is prohibitively long ( $>6 \mathrm{~d}$, McLaren et al. 1988). The high mortality exhibited by C. finmarchicus eggs after short exposures to UV-B implies that UV-B radiation may exert a countervailing selective pressure which favours release of eggs deeper in the water column or the production of negatively buoyant eggs: both would increase the probability of their loss to the cold intermediate layer.

Of the copepod species that predominate in subarctic planktonic communities, Calanus finmarchicus may be among those most vulnerable to UV-B radiation. Calanus hyperboreus, the other dominant calanoid copepod in the deep waters of the Gulf of St. Lawrence, releases eggs at depth in late winter through early spring (Conover 1988). Thus, their eggs are not exposed to UV-B radiation, although naupliar stages residing in the surface mixed layer later in spring and early summer might be. The calanoid cope- pod Pseudocalanus sp. and the cyclopoid copepod Oithona sp. carry their eggs until hatching: it is possible, therefore, that females protect their eggs from UV$B$ exposure by maintaining a depth in the mixed layer below that to which UV-B penetrates. Temora longicornis, a calanoid copepod dominant on the shallow Magdalen Plateau in the southern Gulf of St. Lawrence, releases highly pigmented eggs into the water: although the photoprotective qualities of this pigment are presently unknown, they may protect eggs from UV-B-induced damage (see Ringelberg et al. 1984, Zellmer 1995, Zagarese et al. 1997). Metridia longa, another common calanoid species in the Gulf of St. Lawrence, although less abundant than $C$. finmarchicus, broadcasts unpigmented eggs and may also be susceptible to UV-B.

Exposure to UV-B radiation may be even more damaging than suggested by results on egg mortality alone. Even short (sublethal) exposures to UV-B produced a significant proportion of deformed first stage nauplii which were clearly nonviable. This was particularly significant in the $312 \mathrm{~nm}$ treatment, in which abnormal naupliar development accounted for approximately $30 \%$ of all nonviable progeny (eggs and nauplii) (Kouwenberg et al. 1999b, their Fig. 1).

Atlantic cod. The work of Marinaro \& Bernard (1966), Pommeranz (1974) and Hunter et al. (1979, 1981, 1982) provided clear evidence of the detrimental effect of UV-B on the planktonic early life stages of marine fishes. Hunter et al. (1979), working with northern anchovy Engraulis mordax and Pacific mackerel Scomber japonicus embryos and larvae, reported that exposure to surface levels of UV-B could be lethal. Significant sublethal effects were also reported: lesions in the brain and retina, and reduced growth rate. The study concluded that, under some conditions, $13 \%$ of the annual production of northern anchovy larvae could be lost as a result of UV-B related mortality (Hunter et al. 1981, 1982).

With the exception of a small number of recent studies (Malloy et al. 1997, Williamson et al. 1997, Freitag et al. 1998, Vetter et al. 1999), very little additional information has been generated for the effects of UV-B on ichthyoplankton. The results presented here substantiate earlier results on the lethal effects of UV-B on planktonic fish eggs and provide the first BWF and only the second assessment of the reciprocity principle generated for a marine fish.

Predictions of UV-induced mortality in Calanus finmarchicus and cod. Biologically weighted radiant exposure- $H^{*}$ (Eq. 2)-is obtained by combining spectral irradiance and exposure time with the BWFs for either $C$. finmarchicus or cod egg mortality. A more ecologically meaningful analysis is possible from Eq. (2) which, since the second order mortality term 
$(M)$ is essentially 0 (see Kouwenberg et al. 1999a, b), reduces to:

$$
\frac{\operatorname{Egg}(d)}{\operatorname{Egg}(0)}=e^{-H^{*}}
$$

Under any spectral irradiance, the $H^{*}$ that yields, for example, $\operatorname{Egg}(d) / \operatorname{Egg}(0)=0.5$ is calculated. This value then allows Eq. (3) to be solved for $t_{\mathrm{uv}}$, the exposure time resulting in $50 \%$ egg mortality.

Under current noon surface irradiance, $50 \%$ of Calanus finmarchicus eggs located at or very near the ocean surface will be dead after $2.5 \mathrm{~h}$ of exposure. The analogous time for $50 \%$ mortality in cod eggs is $42 \mathrm{~h}$. Under solar spectral irradiance simulating $20 \%$ ozone thinning, this time drops to $2.2 \mathrm{~h}$ for $C$. finmarchicus eggs at the surface, and $32 \mathrm{~h}$ for cod eggs. In this geographic region, seasonal minima in ozone layer thicknesses occur during the winter and early spring. Thus, only the very beginning of the $C$. finmarchicus or cod spawning seasons occur under (seasonally) thinned ozone.

The depth at which eggs are suspended in the water column-and the diffuse attenuation coefficient for UV-B wavelengths exhibited by the water-will also affect their susceptibility to UV-B. We calculated (as above) that $50 \%$ of Calanus finmarchicus eggs incubated under $50 \mathrm{~cm}$ of water from the maritime estuary of the St. Lawrence River would be dead after $4.6 \mathrm{~h}$ of exposure to the noon-time sun-double the time calculated for the surface. The time was $83 \mathrm{~h}$ for cod eggs, also double the value for a surface exposure.

In an outdoor exposure experiment with the freshwater calanoid copepod Diaptomus sp., significant mortality in eggs and nauplii was observed after nearsurface exposures of $3 \mathrm{~d}$ or less (Williamson et al. 1994). In our own exposure experiment with cod (above), approximately $60 \%$ of the eggs died after $4 \mathrm{~d}$ of incubation in quartz tubes held at $5 \mathrm{~cm}$ depth (Béland et al. 1999). In a similar experiment, approximately $90 \%$ of yellow perch eggs were dead after $6 \mathrm{~d}$ (Williamson et al. 1997). These values are of the same order of magnitude as the above estimates.

The estimates presented above are based upon irradiance taken at a time of day during which the values would be maximal, and upon a worst case scenario $B W F$. Nonetheless, they illustrate the relative changes in UV-B impacts that result from seasonal changes in ozone layer thickness, and/or from depletions expected over the coming decades (Kerr \& McElroy 1993, Graedel \& Crutzen 1995, Fergusson \& Wardle 1998).

\section{Indirect effects of $\mathrm{UV}$ radiation}

The great majority of UV-B radiation research examines direct effects on specific organisms. The few studies that have investigated indirect effects illustrate how UV-B-induced changes in food-chain interactions can be far more significant than direct effects on individual organisms at any single trophic level (e.g. Bothwell et al. 1994, Williamson et al. 1999, and see discussion in Hessen et al. 1997). Recent investigations point to the possibility of such a foodchain effect in both marine and freshwaters: UV-B exposure (even at low dose rates) reduces the total lipid content of some microalgae (Arts \& Rai 1997. Plante \& Arts 1998, Arts et al. 2000): this effect includes the polyunsaturated fatty acids (PUFAs) (Goes et al. 1994, Wang \& Chai 1994, Hessen et al. 1997). For zooplankton and fish larvae, the only source of these fatty acids is dietary-since they cannot synthesize PUFAs de novo, they must be obtained through prey organisms (e.g. Goulden \& Place 1990, Rainuzzo et al. 1997, Reitan et al. 1997, Sargent et al. 1997). Dietary deficiencies of these fatty acids are manifested in many ways. For example, in the freshwater cladoceran Daphnia spp., growth rates are correlated with the sestonic content of eicosapentaenoic acid (Müller-Navarra 1995a, b, also see De Lange \& Van Donk 1997). In Atlantic herring Clupea harengus, dietary deficits of essential fatty acids, in particular docosahexaenoic acid, reduces the number of rods in the eyes (Bell \& Dick 1993) and also negatively affects the feeding of these fish under low light intensities (Bell et al. 1995, also see Masuda et al. 1998). Other negative consequences of essential fatty acid deficits have also been reported (e.g. Kanazawa 1997, Rainuzzo et al. 1997, Bell et al. 1998). A UV-B-induced reduction in the PUFA content of microalgae will be passed on to the herbivorous zooplankton that graze upon them, thereby also decreasing the levels of this essential nutrient that are available to be taken up by fish larvae. Since fish larvae (and their prey) require these essential fatty acids for proper development and growth, such a reduction in the nutritional quality of the food base has potentially widespread and significant implications for the overall productivity and health of aquatic ecosystems.

Exposure to UV radiation, especially UV-B, has many harmful effects on animal health. These may result in poorer performance, or death, even though they are not directly induced by the UV exposure. UV-B suppresses both systemic and local immune responses to a variety of antigens, including microorganisms (Hurks et al. 1994, Garssen et al. 1998). In addition to suppressing T-cell-mediated immune reactions, UV-B also affects nonspecific cellular immune defences. Recent studies demonstrate disturbed immunological responses in UV-B-irradiated roach Rutilus rutilus $\mathrm{L}$.: the function of isolated head kidney neutrophils and macrophages (immuno-responsive 
cells) were significantly altered after a single dose of UV-B (Salo et al. 1998). Further, natural cytotoxicity, assumed to be an important defence mechanism in viral, neoplastic and parasitic diseases, was reduced. A single UV-B exposure decreased the ability of fish lymphocytes to respond to activators, and the reduction was still visible $14 \mathrm{~d}$ after the single exposure (Jokinen et al. unpubl.). This indicates altered regulation of lymphocyte-dependent immune functions. Finally, exposure to UV-B induces a strong systemic stress response which is manifested in the fish's blood by an increased number of circulating phagocytes and elevated plasma cortisol levels (Salo et al. 2000). Since high cortisol levels induce immunosuppression in fishes (Bonga 1997) it is now clear that the effect of UV-B exposure on the immune system has both direct and indirect components. Taken together, these findings strongly suggest that the immune system of fishes is significantly impacted by exposure to a single, moderate-level dose of UV-B radiation. At the population level, such a reduction in immune response might be manifested as lowered resistance to pathogens and in increased susceptibility to diseases. The ability of the fish immune system to accommodate increases in solar UV-B radiation are unknown. Further, the immune system of young fishes is likely highly vulnerable to UV-B radiation because lymphoid organs are rapidly developing and critical phases of cell proliferation, differentiation and maturation are occurring (Grace \& Manning 1980, Botham \& Manning 1981, Chilmonczyk 1992). It is also possible that exposure to ambient UV-B radiation impedes the development of the thymus or other lymphoid organs resulting in compromised immune defence later in life. The effect of UV radiation on the immune function of fish embryos and larvae, and on the development of the immune system, is unknown.

Other indirect effects of UV radiation are also possible. For example, for species that spawn in the surface layer, UV-B may affect sperm quality (sensu Don \& Avtalion 1993, Valcarcel et al. 1994) and thereby affect fertilization rate and/or genome transfer. Also, if UV reduces the productivity of protozoans and crustacean zooplankton, there will be less prey available for fish larvae and other organisms that feed upon them. Finally, existing studies of UV-B impacts have almost all examined the effects of short-term exposure on biological end-points such as skin injury (sunburn), DNA damage, development and growth rates, immune function or outright mortality. To date, few studies have examined the potential effects of longer-term (lowlevel) UV-B exposures (but see Fidhiany \& Winckler 1999).

All of these indirect (and/or longer-term) effects of UV radiation have yet to be investigated. These will be the focus of our future investigations.

\section{A SIMULATION MODEL FOR UV-B-INDUCED MORTALITY}

All of the preceding represents the building blocks necessary to predict the ecological significance of UV$B$ radiation on the population dynamics of planktonic organisms-in this case, the early life stages of Calanus finmarchicus and Atlantic cod in the Gulf of St. Lawrence. A more complete quantitative assessment of direct UV-B effects on these planktonic life stages requires further information and analysis. Specifically, (1) detailed vertical distributions of eggs in the mixed layer of the water column (with high resolution in the upper $10 \mathrm{~m}$ ); (2) surface UV-B irradiance during the reproductive season, and subsurface spectral irradiance for waters supporting such eggs (see Kuhn et al. 1999); (3) biological weighting functionswhich explicitly consider the possibility of photorepair (and, therefore, the absence of reciprocity) - for the effect of UV-B radiation on egg mortality (see Kouwenberg et al. 1999a,b); and (4) a model to predict the vertical position of passive particles (such as eggs) in the mixed layer, and particularly their daily residence time near the surface under various meteorological and hydrographic conditions. All of these components can be incorporated into a broader simulation model to provide an assessment of UV-B effects on a population of eggs distributed (and circulating) throughout the mixed layer (e.g. Neale et al. 1998). We have recently developed such a model (Kuhn et al. 2000).

The model incorporates all of the physical and biological information listed above and generates an absolute estimate of mortality under different meteorological and hydrographic conditions. As a result, the relative impacts of differing combinations of environmental conditions - for example, clear versus overcast skies; clear versus opaque water column; ambient versus thinned ozone layer-can be evaluated.

\section{The physical model}

A Langrangian vertical mixing model (Visser 1997) was used to trace diurnal changes in the depth $\left(z_{1}\right.$ in meters) distribution of particles (Calanus finmarchicus or cod eggs) through a homogenous mixed water column of varying depth. Eggs were mixed every $3 \mathrm{~min}$ $(\Delta t)$ throughout the day. The model's solar radiation subcomponent generates surface downwelling spectral irradiance at a temporal resolution matching the mixing frequency of the model's vertical mixing component. Various ozone losses were modelling and percentage increases in surface irradiance were calculated using a delta-Eddington radiative transfer algorithm (Davies et al. 2000). Irradiance at depth was 
calculated using Beer's law. Diffuse attenuation coefficients were calculated by applying Beer's law to the spectral downwelling irradiance measurements made in the estuary and Gulf of St. Lawrence.

\section{The biological model}

Biologically weighted exposure $\left(H_{\text {inh }}\right)$ was calculated using the biological weighting for the mortality of either Calanus finmarchicus or cod eggs. $H_{\text {inh }}$ was calculated-and accumulated-for each 3 min time step $(\Delta t)$. At the end of the mixing period (1 d), the negative exponent of the summed $H_{\text {inh }}$ determines the probability of mortality $(M)$. Finally, $M$ is compared with a uniformly distributed random number ranging from 0 to 1 . If $M$ is less than the random number, the egg is considered dead. If $M$ is greater than the random number, the egg survives to the next time step.

This is an individual-based model, so it is run iteratively on several thousand eggs. The output is the percent of eggs that have died as a result of exposure to UV-B.

\section{Model predictions}

For Calanus finmarchicus eggs, UV-B-induced mortality under all model scenarios ranged between $<1$ and $32.5 \%$, with a mean $( \pm \mathrm{SD})$ of $7.6 \pm 8.3 \%(\mathrm{n}=48$ modelled scenarios). For cod, none of the model scenarios produced a UV-B-induced mortality $>1.2 \%$, with a mean $( \pm S D)$ of $0.64 \pm 0.42 \%(n=72$ modelled scenarios). This result is consistent with the data presented above-C. finmarchicus eggs are more susceptible to UV-B radiation than are cod eggs. Complete details of the model, and the scenarios evaluated, are reported in Kuhn et al. (2000).

\section{PARTING WORDS OF CAUTION}

It is important to point out that variability in cloud cover, water quality, and vertical distribution and displacement within the mixed layer will likely all have a greater effect on the flux of UV-B radiation to which the eggs of zooplankton and fishes are exposed than will ozone layer depletion at these latitudes. Thus, although UV-B radiation can have negative impacts (direct effects) on crustacean zooplankton and ichthyoplankton populations, it must be viewed as only 1 amongst many environmental factors-bacterial and/or viral pathogens, predation, toxic algae, etc. that produce the mortality typically observed in the planktonic early life stages of these organismal groups.
For zooplankton and fish species whose early life stages are distributed throughout the mixed layer, it seems most likely that UV-B radiation would represent only a minor source of direct mortality for the population. However, for those species whose early life stages are neustonic, there may be circumstances (albeit rare)-cloudless sky, thin ozone layer, no wind, calm seas-under which the contribution of UV-B radiation to the population's mortality could be much more significant. Simulation models such as that described here allow quantification, in a relative sense at least, of the direct contribution made by UV-B radiation to overall mortality under varying atmospheric and oceanographic conditions. The impact of indirect effectswhich may well be of much greater import to marine populations and ecosystems - have yet to be evaluated.

Acknowledgements. We are grateful for the assistance of the following friends and colleagues: Marise Bélanger, Michel Boulé, Jay Bugden, Réal Gagnon, Chris Hazzi, David Hirschberg, Pierre Joly, Paul Kepkay, Barbara Nieke, Herman ten Napel, Norm Scully and Edmund Wu. The insightful comments and suggestions of 4 anonymous reviewers significantly improved the quality of the presentation. The biological impact components of this project were supported by grants in aid of research from the Department of Fisheries and Oceans Canada, the St. Lawrence Vision 2000 Program and the Natural Sciences and Engineering Research Council of Canada (NSERC) to H.I.B. and J.A.R. The optical and meteorological components were supported from these sources and also by grants in aid of research from Environment Canada's Atmospheric Environment Program to B.M. J.H.M.K. was supported by a Visiting Postdoctoral Fellowship at Canada's Department of Fisheries and Oceans Maurice-Lamontagne Institute. J.J.C. and R.F.D. were supported by the NSERC Research Partnership Program. C.A.R. and F.B. were supported by graduate student stipends from the NSERC operating grant awarded to H.l.B. C.A.R. also received a Foreign Fees Waiver from the Québec Ministry of Education.

\section{LITERATURE CITED}

Achey PM, Woodhead AD, Setlow RB (1979) Photoreactivation of pyrimidine dimers in DNA from thyroid cells of the teleost, Poicilia formosa. Photochem Photobiol 229: 305-310

Ahmed FE, Setlow RB (1993) Ultraviolet radiation-induced DNA damage and its photorepair in the skin of the platyfish Xiphophorus. Cancer Res 53:2249-2255

Alonso Rodriguez C, Browman HI, Runge JA, St-Pierre JF (2000) Impact of solar ultraviolet radiation on hatching of a marine copepod, Calanus finmarchicus. Mar Ecol Prog Ser 193:85-93

Anderson JT, de Young B (1995) Application of a one-dimensional model to vertical distributions of cod eggs on the northeastern Newfoundland shelf. Can J Fish Aquat Sci 52:1978-1989

Applegate L, Ley R (1988) Ultraviolet radiation-induced lethality and repair of pyrimidine dimers in fish embryos. Mutat Res 198:85-92 
Arts MT, Rai $H$ (1997) Effects of enhanced ultraviolet-B radiation on the production of lipid, polysaccharide and protein in three freshwater algal species. Freshw Biol 38:597-610

Arts MT, Rai H, Tumber VP (2000) Effects of artificial UV-A and UV-B radiation on carbon allocation in Synechococcus elongatus (cyanobacterium) and Nitzschia palea (diatom). Verh Int Verein Limnol 27:(in press)

Bass EL, Sistrun SN (1997) Effect of UV-A radiation on development and hatching success in Oryzias latipes, the Japanese medaka. Bull Environ Contam Toxicol 59: $537-542$

Beer JZ, Olvey KM, Miller SA, Thomas DP, Godar DE (1993) Non-nuclear damage and cell lysis are induced by UVA, but not UVB or UVC, radiation in three strains of L5178Y cells. Photochem Photobiol 58:676-681

Béland F, Browman HI, Alonso Rodriguez C, St-Pierre J-F (1999) The effect of solar ultraviolet radiation $(280-400$ $\mathrm{nm}$ ) on the eggs and larvae of Atlantic cod (Gadus morhua). Can J Fish Aquat Sci 56:1058-1067

Bell MV, Dick JR (1993) The appearance of rods in the eyes of herring and increased didocosahexaenoyl molecular species of phospholipids. J Mar Biol Assoc UK 73:679-688

Bell JG, Batty RS, Dick JR, Fretwell K, Navarro JC, Sargent JR (1995) Dietary deficiency of docosahexaenoic acid impairs vision at low light intensities in juvenile herring (Clupea harengus L.). Lipids 26:565-573

Bell JG, Tocher DR, Farndale BM, Sargent JR (1998) Growth, mortality, tissue histopathology and fatty acid compositions, eicosanoid production and response to stress, in juvenile turbot fed diets rich in gamma-linolenic acid in combination with eicosapentaenoic acid or docosahexaenoic acid. Prostaglandins Leukot Essent Fatty Acids $58: 353-364$

Björn LO, Callaghan TV, Gehrke C, Johanson U, Soneson M Gwyn-Jones D (1998) The problem of ozone depletion in northern Europe. Ambio 27:275-279

Bonga SEW (1997) The stress response in fish. Physiol Rev 77 591-625

Booth CR, Morrow JH (1997) The penetration of UV into natural waters. Photochem Photobiol 65:254-257

Booth CR, Morrow JH, Coohill TP, Cullen JJ, Frederick JE, Häder DP, Holm-Hansen O, Jeffrey WH, Mitchell DL, Neale PJ, Sobolev I, van der Leun J, Worrest RC (1997) Impacts of solar UVR on aquatic microorganisms. Photochem Photobiol 65:252-269

Botham JW, Manning $\mathrm{J}$ (1981) The histogenesis of the lymphoid organs in the carp Cyprinus carpio L. and the ontogenetic development of allograft reactivity. J Fish Biol 19: 403-414

Bothwell ML, Sherbot DMJ, Pollock CM (1994) Ecosystem response to solar ultraviolet-B radiation: influence of trophic-level interactions. Science 265:97-100

Brander KM (1994) Spawning and life history information for North Atlantic cod stocks. ICES Coop Res Rep No 205, International Council for the Exploration of the Sea, Copenhagen, Denmark

Buma AGJ, Engelen AH, Gieskes WWC (1997) Wavelengthdependent induction of thymine dimers and growth rate reduction in the marine diatom Cyclotella sp. exposed to ultraviolet radiation. Mar Ecol Prog Ser 153:91-97

Chalker-Scott L (1995) Survival and sex ratios of the intertidal copepod, Tigriopus californicus, following ultraviolet- $B$ $(290-320 \mathrm{~nm})$ radiation exposure. Mar Biol 123:799-804

Chilmonczyk S (1992) The thymys in fish: development and possible function in the immune response. Annu Rev Fish Dis 2:181-200
Conover RJ (1988) Comparative life histories in the genera Calanus and Neocalanus in high latitudes of the northern hemisphere. Hydrobiologia 167/168:127-142

Coohill TP (1991) Action spectra again? Photochem Photobiol $54: 859-870$

Crutzen PJ (1992) UItraviolet on the increase. Nature 356: 104-105

Cullen JJ, Neale PJ (1994) Ultraviolet radiation, ozone depletion, and marine photosynthesis. Photosynth Res 39: $303-320$

Cullen JJ, Neale PJ (1997) Biological weighting functions for describing the effects of ultraviolet radiation on aquatic systems. In: Häder DP (ed) The effects of ozone depletion on aquatic ecosystems. RG Landes, Austin, TX, p 97-118

Cullen JJ, Neale PJ, L̀esser MP (1992) Biological weighting function for the inhibition of phytoplankton photosynthesis by ultraviolet radiation. Science 258:646-650

Damkaer DM (1982) Possible influences of solar UV radiation in the evolution of marine zooplankton. In: Calkins $\mathrm{J}$ (ed) The role of solar ultraviolet radiation in marine ecosystems. Plenum Press, New York, p 701-706

Davies JA, Kuhn PS, Duhammel G, Runnals K (2000) An ultraviolet $(290-325 \mathrm{~nm})$ irradiation model for Canada. Phys Geogr (in press)

De Gruijl FR, Sterenborg HJCM, Slaper H, van der Leun JC (1986) Dose and dose rate responses to UV-B radiation: implications for reciprocity. In: Worrest RC, Caldwell MM (eds) Stratospheric ozone reduction, solar ultraviolet radiation and plant Life. Springer-Verlag, Berlin, p 119-126

de Lafontaine Y, Demers S, Runge J (1991) Pelagic food web interactions and productivity in the Gulf of St. Lawrence: a perspective. In: Therriault JC (ed) The Gulf of St. Lawrence: small ocean or big estuary? Can Spec Publ Fish Aquat Sci 113:99-123

DeLange HJ, VanDonk E (1997) Effects of UVB-irradiated microalgae on life history traits of Daphnia pulex. Freshw Biol 38:711-720

Dey DB, Damkaer DM, Heron GA (1988) UV-B/dose responses of seasonally abundant copepods of Puget Sound. Oecologia 76:321-329

Don J, Avtalion RR (1993) Ultraviolet irradiation of tilapia spermatozoa and the Hertwig effect: electron microscopic analysis. J Fish Biol 42:1-14

Fergusson A, Wardle DI (1998) Arctic ozone: the sensitivity of the ozone layer to chemical depletion and climate change. Minister of Public Works and Government Services, Catalogue No. EN56-133/1998E, Ottawa

Fidhiany L, Winckler K (1999) Long term observation on several growth parameters of convict cichlid under an enhanced ultraviolet-A $(320-400 \mathrm{~nm})$ irradiation. Aquac lnt 7:1-12

Fortier L, Levasseur ME, Drolet R, Therriault JC (1992) Export production and the distribution of fish larvae and their prey in a coastal jet frontal system. Mar Ecol Prog Ser 85: 203-218

Franklin LA, Forster RM (1997) The changing irradiance environment: consequences for marine macrophyte physiology, productivity and ecology. Eur J Phycol 32:207-232

Freitag JF, Steeger HU, Storz UC, Paul RJ (1998) Sublethal impairment of respiratory control in plaice (Pleuronectes platessa) larvae induced by UV-B radiation, determined using a novel biocybernetical approach. Mar Biol 132:1-8

Garssen J, Norval M, ElGhorr A, Gibbs NK, Jones CD, Cerimele D, DeSimone C, Caffieri S, DallAcqua F, DeGruijl FR, Sontag Y, Van Loveren H (1998) Estimation of the effect of increasing UVB exposure on the human immune system and related resistance to infectious diseases and tumours. J Photochem Photobiol 42:167-179 
Gilbert D, Pettigrew B (1997) Interannual variability (1948-1994) of the CIL core temperature in the Gulf of St. Lawrence. Can J Fish Aquat Sci 54(Suppl 1):57-67

Goes JI, Handa N, Taguchi S, Hama T (1994) Effect of UV-B radiation on the fatty acid composition of the marine phytoplankton Tetraselmis sp.: relationship to cellular pigments. Mar Ecol Prog Ser 114:259-274

Goulden CE, Place AR (1990) Fatty acid synthesis and accumulation rates in daphnids. J Exp Zool 256:168-178

Goutail F, Pommereau JP, Phillips C, Deniel C, Sarkissian A, Lefèvre F, Kyro E, Rummukainen M, Ericksen $P$, Andersen SB, Kaastad-Hoiskar BA, Braathen G, Dorokhov V, Khattatov VU (1999) Depletion of column ozone in the Arctic during the winters of 1993-94 and 1994-95. J Atmos Chem 32:1-34

Grace MF, Manning MJ (1980) Histogenesis of the lymphoid organs in rainbow trout, Salmo gairdneri. Dev Comp Immunol 4:255-264

Graedel TH, Crutzen PJ (1995) Atmosphere, climate, and change. WH Freeman and Company, New York

Grainger EH (1963) Copepods of the genus Calanus as indicators of eastern Canadian waters. R Soc Can Spec Publ 5 68-94

Häder DP (ed) (1997) The effects of ozone depletion on aquatic ecosystems. RG Landes Company, Austin, TX

Häder DP, Worrest RC, Kumar HD, Smith RC (1995) Effects of increased solar ultraviolet radiation on aquatic ecosystems. Ambio 24:174-180

Hearst JE (1995) The structure of photolyase: using photon energy for DNA repair. Science 268:1858-1859

Hessen DO (1994) Daphnia responses to UV-light. Arch Hydrobiol Suppl 43:185-195

Hessen DO, DeLange HJ, Van Donk E (1997) UV-induced changes in phytoplankton cells and its effects on grazers. Freshw Biol 38:513-524

Holm-Hansen O, Lubin D, Helbling EW (1993) Ultraviolet radiation and its effects on organisms in aquatic environments. ln: Young AR, Björn LO, Moan J, Nultsch W (eds) Environmental UV Photobiology. Plenum Press, New York, p 379-425

Hunter JR, Taylor JH, Moser HG (1979) Effect of ultraviolet irradiation on eggs and larvae of the northern anchovy, Engraulis mordax, and the Pacific mackerel, Scomber japonicus, during the embryonic stage. Photochem Photobiol 29:325-338

Hunter JR, Kaupp SE, Taylor JH (1981) Effects of solar and artificial ultraviolet-B radiation on larval northern anchovy, Engraulis mordax. Photochem Photobiol 34:477-486

Hunter JR, Kaupp SE, Taylor JH (1982) Assessment of effects of UV radiation on marine fish larvae. In: Calkins $\mathrm{J}$ (ed) The role of solar ultraviolet radiation in marine ecosystems. Plenum Press, New York, p 459-493

Hurks M, Garssen J, van Loveren H, Vermeer BJ (1994) General aspects of UV-irradiation on the immune system. In Jori G, Pottier RH, Rodgers MAJ, Truscott TC (eds) Photobiology in medicine. Plenum Press, New York, p 161-176

Kanazawa A (1997) Effects of docosahexaenoic acid and phospholipids on stress tolerance of fish. Aquaculture 155: 129-134

Karanas JJ, Van Dyke H, Worrest RC (1979) Midultraviolet (UV-B) sensitivity of Acartia clausii Giesbrecht (Copepoda). Limnol Oceanogr 24:1104-1116

Karanas JJ, Worrest RC, Van Dyke H (1981) Impact of UV-B radiation on the fecundity of the copepod Acartia clausii. Mar Biol 65:125-133

Kaup SE, Hunter JR (1981) Photorepair in larval anchovy, Engraulis mordax. Photochem Photobiol 33:253-256
Kerr JB, McElroy CT (1993) Evidence for large upward trends of ultraviolet-B radiation linked to ozone depletion. Science 262:1032-1034

Koutitonsky VG, Bugden GL (1991) The physical oceanography of the Gulf of St. Lawrence: a review with emphasis on the synoptic variability of the motion. Can Spec Publ Fish Aquat Sci 113:57-90

Kouwenberg JHM, Browman HI, Cullen JJ, Davis RF, StPierre JF, Runge JA (1999a) Biological weighting of ultraviolet (280-400 nm) induced mortality in marine zooplankton and fish. l. Atlantic cod (Gadus morhua) eggs. Mar Biol 134:269--284

Kouwenberg JHM, Browman HI, Runge JA, Cullen JJ, Davis RF, St-Pierre JF (1999b) Biological weighting of ultraviolet $(280-400 \mathrm{~nm})$ induced mortality in marine zooplankton and fish. II. Calanus finmarchicus eggs. Mar Biol 134:285-293

Kuhn P, Browman Hl, St-Pierre JF, McArthur B (1999) Penetration of ultraviolet radiation in the waters of the estuary and Gulf of St. Lawrence. Limnol Oceanogr 44:710-716

Kuhn P, Browman HI, Davis R, Cullen JJ, McArthur B (2000) Modelling the effects of ultraviolet radiation on early life history stages of Calanus finmarchicus and Atlantic cod (Gadus morhua) in a mixing environment. Limnol Oceanogr (in press)

Laurion I, Vincent WF, Lean DRS (1997) Underwater ultraviolet radiation: development of spectral models for northern high latitude lakes. Photochem Photobiol 65:107-114

Lesser MP, Shick JM (1989) Effects of irradiance and ultraviolet radiation on photoadaptation in the zooxanthellae of Aiptasia pallida: primary production, photoinhibition and enzymic defenses against oxygen toxicity. Mar Biol 102: 243-255

Lough RG, Caldarone EM, Rotunno TK, Broughton EA, Burns BR، Buckley LJ (1996) Vertical distribution of cod and haddock eggs and larvae, feeding and condition in stratified and mixed waters on southern Georges Bank, May 1992. Deep-Sea Res Part II Top Stud Oceanogr 43:1875-1904

Lubin D, Frederick JE (1991) The ultraviolet radiation environment of the Antarctic peninsula: the roles of ozone and cloud cover. J Appl Meteorol 30:478-493

Madronich S (1993) The atmosphere and UV-B radiation at ground level. In: Young AR, Björn LO, Moan J, Nultsch W (eds) Environmental UV photobiology. Plenum Press, New York, p 1-39

Madronich S (1994) Increases in biologically-damaging UV-B radiation due to stratospheric ozone reductions: a brief review. Adv Limnol 43:17-30

Madronich S, McKenzie RL, Caldwell MM, Bjorn LO (1995) Changes in ultraviolet radiation reaching the Earth's surface. Ambio 24:143-152

Malloy KD, Holman MA, Mitchell D, William Detrich H (1997) Solar UV-B-induced DNA damage and photoenzymatic DNA repair in antarctic zooplankton. Proc Natl Acad Sci USA $94: 1258-1263$

Marinaro J, Bernard M (1966) Contribution à l'étude des oeufs et larves pélagiques de poissons méditerranés. I. Note preliminaires sur l'influence léthale du rayonnement solaire sur les oeufs. Pelagos 6:49-55

Marshall SM, Orr AP (1955) The biology of a marine copepod. Springer-Verlag, New York

Masuda R, Takeuchi T, Tsukamoto K, Ishizaki Y, Kanematsu $M$, Imaizumi $K$ (1998) Critical involvement of dietary docosahexaenoic acid in the ontogeny of schooling behaviour in the yellowtail. J Fish Biol 53:47 1-484

McLaren IA, Sevigny JM, Corckett CJ (1988) Body sizes development rates and genome sizes among Calanus species. Hydrobiologia 167/168:275-284 
Mitani H, Uchida N, Shima A (1996) Induction of cyclobutane pyrimidine dimer photolyase in cultured fish cells by UVA and blue light. Photochem Photobiol 64:943-948

Mitchell DL, Karentz D (1993) The induction and repair of DNA photodamage in the environment. In: Young AR, Björn LO, Moan J, Nultsch W (eds) Environmental UV photobiology. Plenum Press, New York, p 345-378

Mitchell DL, Travis Scoggins J, Morizot DC (1993) DNA repair in the variable platyfish (Xiphophorus variatus) irradiated in vivo with ultraviolet B light. Photochem Photobiol 58:455-459

Morris DP, Zagarese H, Williamson CE, Balseiro EG, Haragreaves BR, Modenutti B, Moeller R, Queimalinos C (1995) The attenuation of solar UV radiation in lakes and the role of dissolved organic carbon. Limnol Oceanogr 40 : 1381-1391

Mueller JL, Austin RW (1995) Ocean optics protocols for sea WiFS validation, Vol. 25. In: SeaWiFS Technical Report Series, NASA Tech Mem 104566. Greenbelt, MA, p 24-25

Müller-Navarra D (1995a) Evidence that a highly unsaturated fatty acid limits Daphnia growth in nature. Arch Hydrobiol 132:297-307

Müller-Navarra D (1995b) Biochemical versus mineral limitation in Daphnia. Limnol Oceanogr 40:1209-1214

Naganuma T, lnoue T, Uye S (1997) Photoreactivation of UVinduced damage to embryos of a planktonic copepod. J Plankton Res 19:783-787

Neale PJ, Davis RF, Cullen JJ (1998) Interactive effects of ozone depletion and vertical mixing on photosynthesis of Antarctic phytoplankton. Nature 392:585-589

Németh P, Tóth Z, Nagy Z (1996) Effect of weather conditions on UV-B radiation reaching the earth's surface. J Photochem Photobiol (Ser B) 32:177-181

Ohman MD, Runge JA (1994) Sustained fecundity when phytoplankton resources are in short supply: omnivory by Calanus finmarchicus in the Gulf of St. Lawrence. Limnol Oceanogr 39:21-36

Ouellet P (1997) Characteristics and vertical distribution of Atlantic cod (Gadus morhua) eggs in the northern Gulf of St. Lawrence, and the possible effect of cold water temperature on recruitment. Can J Fish Aquat Sci 54:211-223

Ouellet $P_{1}$ Lambert Y, Castonguay M (1997) Spawning of Atlantic cod (Gadus morhua) in the northern Gulf of St. Lawrence: a study of adult and egg distributions and characteristics. Can J Fish Aquat Sci 54:198-210

Petrie B, Akenhead S, Lazier J, Loder J (1988) The cold intermediate layer on the Labrador and north-east Newfoundland shelves, 1978-1986. NAFO (Northwest Atl Fish Organ) Sci Counc Stud 12:57-69

Piazena H, Häder DP (1994) Penetration of solar UV irradiation in coastal lagoons of the southern Baltic Sea and its effect on phytoplankton communities. Photochem Photobiol 60:463-469

Plante AJ, Arts MT (1998) Photosynthate production in laboratory cultures (UV conditioned and unconditioned) of Cryptomonas erosa under simulated doses of UV radiation. Aquat Ecol 32:297-312

Pommeranz T (1974) Resistance of plaice eggs to mechanical stress and light. In: Blaxter JHS (ed) The early life history of fish. Springer-Verlag, New York, p 397-416

Rainuzzo JR, Reitan KI, Olsen Y (1997) The significance of lipids at early stages of marine fish: a review. Aquaculture 155:103-115

Regan JD, Snyder RD, Francis AA, Olla BL (1983) Excision repair of ultraviolet- and chemically-induced damage in the DNA of fibroblasts derived from two closely related species of marine fishes. Aquat Toxicol (Amst) 4:181-188
Reitan KI, Rainuzzo JR, Øie G, Olsen Y (1997) A review of the nutritional effects of algae in marine fish larvae. Aquaculture 155:207-221

Ringelberg J, Keyser AL, Flik BJG (1984) The mortality effect of ultraviolet radiation in a translucent and in a red morph of Acanthodiaptomus denticornis (Crustacea, Copepoda) and its possible ecological relevance. Hydrobiologia 112: $217-222$

Runge JA, de Lafontaine Y (1996) Characterization of the pelagic ecosystem in surface waters of the northern Gulf of St. Lawrence in early summer: the larval redfishCalanus-microplankton interaction. Fish Oceanogr 5: 21-37

Runge JA, Plourde S (1996) Fecundity characteristics of Calanus finmarchicus in coastal waters of eastern Canada. Ophelia 44:171-187

Salo HM, Aaltonen TM, Markkula SE, Jokinen EI (1998) Ultraviolet $\mathrm{B}$ irradiation modulates the inmune system of fish (Rutilus rutilus, Cyprinidae). I. Phagocytes. Photochem Photobiol 65:957--963

Salo HM, Aaltonen TM, Markkula SE, Jokinen EI (2000) Ultraviolet $B$ irradiation modulates the immune system of fish (Rutilus rutilus, Cyprinidae). II. Blood. Photochem Photobiol 71:65-70

Sargent JR, McEvoy LA, Bell JG (1997) Requirements, presentation and sources of polyunsaturated fatty acids in marine fish larval feeds. Aquaculture 155:117-127

Scully NM, Lean DS (1994) The attenuation of ultraviolet radiation in temperate lakes. Arch Hydrobiol Suppl 43 135-144

Setlow RB (1974) The wavelengths in sunlight effective in producing skin cancer: a theoretical analysis. Proc Natl Acad Sci USA 71:3363-3366

Shima A, Setlow RB (1984) Survival and pyrimidine dimers in cultured fish cells exposed to concurrent sun lamp ultraviolet and photoreactivating radiators. Photochem Photobiol 39:49-56

Shima A, Ikenaga M, Nakaido O, Takebe H, Egami N (1981) Photoreactivation of ultraviolet light-induced damage in cultured fish cells as revealed by increased colony forming ability and decreased content of pyrimidine dimers. Photochem Photobiol 33:313-316

Siebeck O, Vail TL, Williamson CE, Vetter R, Hessen D, Zagarese $\mathbf{H}$, Little E, Balseiro E, Modenutti B, Seva J, Shumate A (1994) Impact of UV-B radiation on zooplankton and fish in pelagic freshwater ecosystems. Adv Limnol 43: 101-114

Smith RC, Baker KS (1979) Penetration of UV-B and biologically effective dose rates in natural waters. Photochem Photobiol 29:311-323

Smith RC, Cullen JJ (1995) Effects of UV radiation on phytoplankton. Rev Geophys 33:1211-1223

Solemdal P, Sundby S (1981) Vertical distribution of pelagic fish eggs in relation to species, spawning behaviour and wind conditions. Int Counc Explor Sea Comm Meet G:77

Stambler N, Lovengreen C, Tilzer MM (1997) The underwater light field in the Bellingshausen and Amundsen Seas (Antarctica). Hydrobiologia 344:41-56

Sutherland BM (1981) Photoreactivation. Bioscience 31: $439-444$

Sutherland BM, Hacham H, Gange RW, Sutherland JC (1992) Pyrimidine dimer formation by UVA radiation: implications for photoreactivation. In: Urbach $F$ (ed) Biological responses to UVA radiation. Valdemar, Overland Park, $\mathrm{KS}, \mathrm{p}$ 47-58

Therriault JC (ed) (1991) The Gulf of St. Lawrence: small 
ocean or big estuary? Can Spec Publ Fish Aquat Sci 113: $1-359$

Thomson BE (1986) Is the impact of UV-B radiation on marine zooplankton of any significance? In: Titus JG (ed) Effects of changes in stratospheric ozone and global climate, Vol. 2. UNEP-USEPA, Washington DC, p 203-209

Valcarcel A, Guerrero G, Maggese MC (1994) Hertwig effect caused by UV-irradiation of sperm of the catfish, Rhamdia sapo (Pisces, Pimelodidae), and its photoreactivation. Aquaculture 128:21-28

Varotsos C, Kalabokas P, Vlassi A, Katsambas A, Stratigos J, Antoniou $C$ (1994) The biologically active ultraviolet radiation in relation to the surface ozone and the wind field. Toxicol Environ Chem 44:233-242

Vetter RD, Kurtzman AL, Mori T (1999) Diel cycles of DNA damage and repair in eggs and larvae of Northern anchovy, Engraulis mordax, exposed to solar ultraviolet radiation. Photochem Photobiol 69:27-33

Visser AW (1997) Using random walk models to simulate the vertical distribution of particles in a turbulent water column. Mar Ecol Prog Ser 158:275-281

Walters C, Ward B (1998) Is solar ultraviolet radiation responsible for declines in marine survival rates of anadromous salmonids that rear in small streams? Can J Fish Aquat Sci 55:2533-2538

Wang KS, Chai T (1994) Reduction in omega-3 fatty acids by UV-B irradiation in microalgae. J Appl Phycol 6:415-421

Wardle DI, Kerr JB, McElroy CT, Francis DR (eds) (1997)

Editorial responsibility: Otto Kinne (Editor),

Oldendorf/Luhe, Germany
Ozone science: a Canadian perspective on the changing ozone layer. Environment Canada, University of Toronto Press, Toronto

Williamson CE, Zagarese HE, Schulze PC, Hargreaves BR, Seva J (1994) The impact of short-term exposure to UV-B radiation on zooplankton communities in north temperate lakes. J Plankton Res 16:205-218

Williamson CE, Metzgar SL, Lovera PA, Moeller RE (1997) Solar ultraviolet radiation and the spawning habitat of yellow perch, Perca flavescens. Ecol Appl 7:1017-1023

Williamson CE, Hargreaves BR, Orr PS, Lovera PA (1999) Does UV radiation play a role in changes in predation and zooplankton community structure in acidified lakes? Limnol Oceanogr 44:774-783

Winckler K, Fidhiany L (1996) Significant influence of UVA on the general metabolism in the growing cichlid fish, Cichlasoma nigrofasciatum. J Photochem Photobiol (Ser B) 33: $131-135$

Zagarese HE, Feldman $M_{i}$ Williamson CE (1997) UV-Binduced damage and photoreactivation in three species of Boeckella (Copepoda, Calanoida). J Plankton Res 19: 357-367

Zellmer ID (1995) UV-B-tolerance of alpine and arctic Daphnia. Hydrobiologia 307:153-159

Zepp RG, Braun AM, Hoigné J, Leenheer JA (1987) Photoproduction of hydrated electrons from natural organic solutes in aquatic environments. Environ Sci Technol 21: $485-490$

Submitted: February 3, 1999; Accepted: December 9, 1999 Proofs received from author(s): May 29, 2000 